\title{
Service Innovation, Embeddedness and Business Performance: Evidence from Northern Ireland
}

\author{
James H Love*, Stephen Roper** and Nola Hewitt-Dundas*** \\ * Economics and Strategy Group, Aston Business School, Aston University, \\ Birmingham, B4 7ET. \\ E-mail: j.h.love@aston.ac.uk \\ ** Centre for Small and Medium-Sized Enterprises, Warwick Business School, \\ University of Warwick, Coventry, CV4 7AL. \\ E-mail: stephen.roper@wbs.ac.uk \\ *** School of Management and Economics, Queen's University Belfast, Belfast, \\ BT7 1NN. \\ E-mail: nm.hewitt@qub.ac.uk
}

\begin{abstract}
We explore the factors which determine innovation by service firms, and in particular the contribution of intra- and extra-regional connectivity. Subsequently we examine how service firms' innovation activity relates to productivity and export behaviour. Our empirical analysis is based on matched data from the 2005 UK Innovation Survey - the UK component of the Fourth CIS - and the Annual Business Inquiry for Northern Ireland. We find evidence of negative intra-regional embeddedness effects, but there is a positive contribution to innovation from extra-regional connectivity, particularly links to customers. Relationships between innovation, exporting and productivity prove complex but suggest that innovation itself is not sufficient to generate productivity improvements. Only when innovation is combined with increased export activity are productivity gains evident.
\end{abstract}

Keywords: Innovation, services, regional development, productivity, exporting, Ireland JEL codes: O31, O18, R11, R15

Acknowledgements: We are grateful for the comments of discussants and participants at the DRUID 2008 Summer Conference, and for the detailed comments of three anonymous referees. 


\section{Service Innovation, Embeddedness and Business Performance: Evidence from Northern Ireland}

\section{Introduction}

An often restated argument is that regions' ability to sustain wealth creation depends on innovation, particularly where labour costs are high. In the UK, this has been recognised in the identification of innovation - along with investment, skills, enterprise and competition - as one of the 'five drivers of productivity' (H M Treasury, 2000). Increasingly, however, it is the service industries rather than manufacturing which is the source of new growth, emphasising the potential importance of service innovation in raising regional productivity. Service innovation may have direct benefits by promoting growth and productivity in the service sector itself. Indirect benefits may also result, however, due to the enabling role of the service sector and its contribution to supporting innovation and growth in other industries and the public sector (e.g. Wood, 2005; Muller and Zenker, 2001; Czarnitzki and Spielkamp, 2003; OECD 2007). Here, we identify the key determinants of innovation by services firms, and the impact of this innovation on productivity and exporting. The results suggest policy lessons both for those interested in increasing services innovation and in generating enhanced regional growth and productivity.

Compared to manufacturing, service industries have long been characterised as having weak IPR regimes, outsourced technological development processes, customer-led innovation (Love and Mansury, 2007), long service lifetimes and an emphasis on intangible market offerings (Howells, 2000a). As a result, studies by Den Hertog, (2000) and de Jong et al. (2003), for example, suggest that service innovation is best described as a process of collective problem solving in which learning within organisations (e.g. Cohen and Levinthal, 1989, 1990; Zahra and George, 2002), and connections between organisations (Tether 2005) play a key role ${ }^{1}$. Love and Mansury (2007), for example, suggest that firms' external linkages, particularly with customers, can significantly enhance service innovation performance. On the same theme, Leiponen (2005) found that completely new services are most often introduced

\footnotetext{
${ }^{1}$ See also Hulshoff et al. (1998), Silvestrou et al. (1992) and Evangelista (2000)
} 
by firms that engage in external knowledge sourcing, particularly from customers and competitors.

The technological characteristics of service production also suggest that there may be differences from manufacturing in terms of the relationships between innovation, business growth, exporting (Wakelin, 1998; Sterlacchini, 1999; Bleaney and Wakelin, 2002; Roper and Love, 2002; Lachenmaier and Wößmann, 2006) and productivity (Lööf and Heshmati, 2001, 2002; Roper et al 2008). However, Cainelli et al (2006), based on Italian Community Innovation Survey data, and Mansury and Love’s (2008) study of US business service firms, do suggest as in manufacturing a strong positive relationship between the introduction of new services, organisational innovation and subsequent economic performance. Gourlay et al (2005) and Blind and Jungmittag (2004) also suggest that R\&D intensity has strong positive effect on both the probability and intensity of exporting of UK and German service firms ${ }^{2}$. Business R\&D may also play an important part in shaping service firms’ absorptive capacity (Zahra and George, 2002), with Veugelers and Cassiman (1999) suggesting that firms undertaking in-house $R \& D$ benefit more from external information sources than companies which have no in-house R\&D activity.

In this paper we adopt an econometric approach to examine the determinants of a range of different types of innovation by services firms and their effects on exporting and productivity performance. In particular, we focus on the impact on innovation of local embeddedness, where we use the term 'embeddedness' to reflect the extent and nature of firms' intra-regional relationships to other organisations. Our choice to examine these relationships at a regional level reflects contrasting arguments in the economic geography literature about the potential advantages or disadvantages of local or regional embeddedness for service firms’ innovation activity. On one hand, Gallaher et al (2006) argue that the spatial scale of service industry innovation systems is more likely to be regional rather than the national or global. This emphasises the importance of intra-regional embeddedness for service innovation and the potential for positive clustering or agglomeration effects. The contrasting view of

\footnotetext{
${ }^{2}$ There is a literature on service sector exporting in the marketing literature, but this is concerned mainly with explaining firms' foreign market entry mode (e.g. exporting versus licensing versus FDI). See Gourlay et al (2005) for a summary.
} 
embeddedness - labelled the 'neo-classical' perspective by Boschma (2005) - instead emphasises the potentially negative lock-in effects of intensive intra-regional connectivity and the positive role of external connectivity. Our empirical analysis focuses on two key questions. First, what factors determine service firms' profile of innovation and, in particular, how important are intra- and extra- regional factors in this process? Second, how is service firms' innovation activity related to subsequent productivity and export behaviour? Here our key interest is in which aspects of firms' innovation activity have the greatest productivity and export benefits. Important, positive intra-regional connectivity effects would provide support for the agglomeration or clustering view of embeddedness; negative intra-regional connectivity effects on innovation and positive external connectivity effects would instead suggest the validity of the 'neo-classical' view outlined by Boschma (2005).

Our empirical analysis focuses on Northern Ireland, a region of the UK with a population of around 1.7 million. Emerging from a long period of political instability, the Northern Ireland economy has performed well in recent years (Fielding 2003) ${ }^{3}$. For example, Northern Ireland experienced the highest employment growth rate (15.6 per cent) of all UK regions over the decade to 2005 with unemployment (4.2 per cent) being the second lowest of the UK regions, and considerably below the UK average of 5.4 per cent. As in much of Europe, manufacturing output and employment in Northern Ireland have declined in recent years although this has been more than offset by growth in services with productivity in Northern Ireland remaining at around 80 per cent of the UK average and close to the average for the EU25. Historically, levels of R\&D investment in Northern Ireland have been low, with many Northern Ireland firms lagging in terms of innovation and technology adoption (Hewitt-Dundas et al. 2002). In 2005, for example, business R\&D in Northern Ireland was equivalent to 0.6 per cent of regional value added (GVA), around half of the UK average of 1.2 per cent. Northern Ireland therefore shares many of the characteristics of other small, peripheral regions in both Europe and elsewhere with future prosperity depending increasingly on service activity and exports.

\footnotetext{
${ }^{3}$ The following economic indicators are derived from DETI (2007) Quarterly Economic Bulletin, Economic Research Summer 2007
} 
The remainder of the paper is organised as follows. Section 2 provides an overview of our conceptual approach, based around the notion of the innovation value chain (Roper et al 2008). Section 3 outlines our data which combines innovation data from the UK Innovation Survey 2005 - the UK element of the $4^{\text {th }}$ Community Innovation Survey - with productivity and exporting information from the Annual Business Inquiry. Sections 4 and 5 describe our empirical analysis which focuses on Northern Ireland, a small UK region with GDP per capita marginally below the EU27 average in $2004^{4}$. Section 6 concludes by identifying the main findings and drawing out the key lessons for regional policy to support service innovation.

\section{Conceptual Approach}

Our interest here is the process through which service firms source, transform and exploit new - and potentially pre-existing - knowledge through innovation. At a fundamental level, this firm-specific process can be seen as part of a broader evolutionary dynamic in which firms' service offerings are steadily refined - and occasionally transformed (Nelson and Winter, 1982). We also emphasise the potential role of the regional knowledge eco-system within which firms operate, and the potential benefits of operating in a regional environment where there exist rich external knowledge sources and extensive networking opportunities (Iansiti and Levien, 2004). At the level of the firm, however, our analysis becomes more deterministic, relating innovation outputs and business performance to firms' internal and acquired knowledge and internal resources. In this sense at least our perspective is consistent with a resource-based or capabilities perspective on business growth and development (e.g. Foss, 2004)

Our conceptual framework is based on the concept of the innovation value chain (IVC). This describes the recursive process through which service firms source the knowledge they need to undertake innovation, transform this knowledge into new services, and then exploit their innovations to generate added value (Roper et al 2008). In the knowledge transformation phase, knowledge sourced externally or created by the enterprise is transformed into innovation outputs. This is modelled using an innovation or knowledge production function (Geroski, 1990; Harris and

\footnotetext{
${ }^{4}$ In 2004, GDP per capita in Northern Ireland was €23,319 or 99 per cent of the EU27 average and 80 per cent of the UK average. Source: Eurostat News Release STAT/07/23, 19 ${ }^{\text {th }}$ February 2007.
} 
Trainor, 1995) in which the effectiveness of knowledge transformation is influenced by enterprise characteristics, the strength of the firm's resource-base, as well as the firm's managerial and organisational capabilities (Griliches, 1992; Love and Roper, 1999). In general terms, we write the innovation production function as:

$$
I_{i}=\phi_{0} K S_{j i}+\phi_{2} R I_{i}+\phi_{3} A C A P_{i}+\phi_{4} B A R_{i}+\phi_{5} G O V T_{i}+\varepsilon_{i}
$$

Where $\mathrm{I}_{\mathrm{i}}$ is an innovation output indicator, and $K S_{j i}$ stands for the $i^{\text {th }}$ firm's knowledge sourcing activity $j$, j=1..6. $R_{i}$ is a set of indicators of firms' resource base and $B A R_{i}$ is a set of indicators of perceived barriers to innovation. $A C A P_{i}$ is a set of indicators intended to reflect firms' absorptive capacity and $G O V_{t}$ reflect access to government support for innovation and upgrading.

In addition to knowledge generated through any investments in in-house $R \& D$, we distinguish here six different routes through which firms can source external knowledge for their innovation activity. The trade-off between these two approaches to knowledge acquisition represents the standard 'make or buy' decision in terms of the literature on technology sourcing (Shelanski and Klein, 1995). First, we allow firms to source or access knowledge relevant for innovation through intra-group knowledge transfers (Howells, 2000b). Second, we allow firms to access external knowledge through backward links to their suppliers. (Horn, 2005), for example, emphasises the increasing significance of backwards integration in R\&D success, while Smith and Tranfield (2005) emphasise the role of such linkages in the UK aerospace industry. Third, we allow firms to generate knowledge inputs for innovation through forward linkages to customers. This may reflect either formal or informal knowledge sharing, but provides an indication of the potential importance of, say, knowledge of customers' preferences in shaping firms' innovation success (Joshi and Sharma, 2004; Love and Mansury, 2007). Fourth, we allow linkages to either competitors (Hemphill, 2003) or through joint ventures. Link et al (2005), for example, identify a range of factors which influence US firms’ participation in research joint ventures including levels of public support for research collaboration (the Advanced Technology Programme) and the general level of prosperity in the US economy. Fifth, we allow for firms’ links to consultants or local private sector 
laboratories (Bessant and Rush, 1995). Finally, we allow for the development by firms of knowledge linkages to universities or other public research centres (Roper, 2004). ${ }^{5}$

There is general evidence that service firms which access external knowledge innovate more successful (Leiponen, 2005) but here we also want to allow for the differential effects on innovation of intra-regional knowledge diffusion or embeddedness (Gertler, 2001), and firms' 'stretched knowledge networks’ involving extra-regional partners (Faulconbridge, 2006). Local links may be particularly beneficial because of the stickiness of knowledge (von Hippel, 1998), greater ease of translating tacit knowledge over personal rather than IT based networks (Audretsch, 1998) and also the greater value of local knowledge in its local context (Gertler, 2004). However, extra-regional connectivity may provide access to best-practice, particularly codified, knowledge from elsewhere with potential benefits for innovation and productivity (Keller, 2004). In our empirical model we therefore include two sets of knowledge sourcing variables relating to firms' intra-regional $\left(\mathrm{KSI}_{\mathrm{i}}\right)$ and extraregional $\left(\mathrm{KSX}_{\mathrm{i}}\right)$ connectivity:

$$
I_{i}=\phi_{0}+\phi_{1} K S I_{j i}+\phi_{2} K S X_{j i}+\phi_{3} R I_{i}+\phi_{4} A C A P_{i}+\phi_{5} B A R_{i}+\phi_{6} G O V T_{i}+\varepsilon_{i}
$$

In terms of the other factors which might influence firms' innovation outputs, we expect a strong internal resource base to contribute positively to the efficiency with which firms develop new innovations (Crépon et al., 1998; Lööf and Heshmati, 2001, 2002). We also expect firms' innovation outputs to be positively related to absorptive capacity (Griffith et al, 2003). Government assistance too we would regard as contributing to, or augmenting, firms' resource base and would therefore anticipate positive coefficients (Link et al, 2005) while the indicators of perceived barriers to innovation we expect to have negative coefficients.

The next link in the innovation value chain is knowledge exploitation, the process by which enterprise performance is influenced by different types of innovation (Roper et al, 2008). We base our analysis here on an augmented production function including

\footnotetext{
${ }^{5}$ These routes to knowledge sources for innovation are consistent with the 'interactional' or 'Schumpeter Mark 3' model of innovation (Gallouj 2002).
} 
the innovation output measures, firms' market position and internal resource base. In terms of the recursive innovation value chain, we regard innovation outputs as predetermined with respect to business performance in the augmented production function. This is expressed as:

$\mathrm{BPERF}_{i}=\lambda_{0}+\lambda_{1} \mathrm{INNO}_{i}+\lambda_{2} X_{i}+\tau_{i}$

Where $B P E R F_{i}$ is an indicator of business performance (e.g. labour productivity or value-added per employee, exporting), $I N N O_{i}$ is a vector of different innovation output measures for different types of service innovation, and $X_{i}$ is a set of enterprise specific variables that are also hypothesized to affect enterprise performance.

\section{Data and Methods}

Two establishment level data sources are used in our analysis. Information about innovation and connectivity is taken from the UK Innovation Survey 2005 - the UK element of the $4^{\text {th }}$ Community Innovation Survey. This covered firms' innovation activities over the period 2002 to 2004, targeting enterprises with more than 10 employees (Robson and Ortmans, 2006). The sampling frame for the UK Innovation Survey was developed from the UK government's Interdepartmental Business Register (IDBR), with the survey being conducted by post. The overall response rate was 53 per cent, with the total of 1359 respondents in Northern Ireland representing around 19 per cent of the target population of 6890 firms (DETI, 2006). Weights were developed to give results which are representative of the Northern Ireland private services sector. The service sectors covered by the sample are shown in Table 1 .

It is now generally accepted that the traditional split between product and process innovation is less meaningful for services than for manufacturing, with product introduction and its delivery closely intertwined (Gallouj and Weinstein, 1997. The empirical literature suggests that, while the concept of innovation is meaningful in services, service firms may not innovate in quite the same way as manufacturers. For example, Tether (2005) shows that service innovation often depends on 'softer', skills-based innovation, relying heavily on the abilities of their workforce and on 
cooperation with outside organizations such as suppliers, customers, and other sources.

Reflecting the work of, inter alia, Djellal and Gallouj (1998) which suggests the diversity of service industry innovation, we here consider six different innovation measures (Table 1). Five of these are dummy variables indicating whether or not a firm undertook innovation of a particular kind over the 2002-04 period. These variables provide an indication of the extent of innovation activity among service industry firms and broaden the scope of measured 'innovation' here beyond the standard product and process categories used in most studies of innovation in manufacturing. More specifically, a firm is said to have undertaken 'service innovation' over the 2002-04 period if it introduced a 'new or significantly improved service'. Similarly, 'strategic innovation' required the implementation of a new or significantly changed corporate strategy. Organisational innovation was said to have occurred where a firm implemented 'major changes to your organisational structure e.g. introduction of cross-functional teams, outsourcing of major business functions', and, marketing innovation required the 'implementation of changes in marketing concepts or strategies, e.g. packaging or presentational changes to a product to target new markets, new support services to open up new markets'. Finally, innovation in advanced management techniques included the new implementation of systems such as knowledge management or Investors in People. Overall, around 13-16 per cent of service firms in Northern Ireland undertook service, marketing, strategic, advanced management techniques (AMT) or organisational innovation over the 2002-04 period. A sixth measure of innovation - the percentage of sales accounted for by services which were new or improved over the previous three years - provides an indication of innovation success. In 2004, an average of 7.0 per cent of firms' sales were derived from such services.

Exporting - defined here as sales outside Northern Ireland - and productivity data are taken from the Annual Business Inquiry ${ }^{6}$. In both cases sampling was undertaken using the IDBR and matching to the UK Innovation Survey (CIS) was therefore

\footnotetext{
${ }^{6}$ See Northern Ireland Annual Business Inquiry 2005, (available at: http://www.detini.gov.uk/cgibin/downdoc?id=2706).
} 
possible using common establishment reference codes. On average, in 2005, exports accounted for 1.7 per cent of firms’ sales with GVA per employee averaging £28,570 (Table 1). One issue with the ABI, however, is that like the CIS it is a sample survey for some firm size-bands. This means that of the c.770 firms covered by the CIS only around 690 were also included in the ABI, with a consequent reduction in sample sizes (see Table 1).

The matched dataset also provides a rich set of variables for each of the elements of equations (1) and (2). Information on intra-regional $\left(K S I_{j i}\right)$ and extra-regional $\left(K S X_{j i}\right)$ connectivity with other organisations which provide knowledge inputs for innovation is derived from the CIS (Table 1). Intra-regional variables here reflect contacts within Northern Ireland and therefore the strength of the regional innovation system. Extraregional contacts are those outside the region and indicate the importance of firms' contacts with more widespread innovation and business networks. Data are available indicating whether each firm had contact with other group companies, suppliers, customers, competitors, laboratories or consultants, and universities. Surprisingly perhaps, given the emphasis placed on connectivity in service innovation (Love and Mansury, 2007), the proportions of firms with external connections as part of their innovation activity are relatively small, with links to local customers (3.4 per cent of firms) and extra-regional suppliers (2.7 per cent of firms) being most common. ${ }^{7}$ Note, therefore, that the CIS data actually measures the degree of connectivity of the surveyed establishments. In line with the conceptual discussion above, we infer these data as being a reasonable proxy for the extent of embeddedness as indicated by Boschma (2005)

The CIS also provides a range of background characteristics on services firms reflecting the availability of internal resources $\left(R I_{i}\right)$. These include $\mathrm{R} \& \mathrm{D}$, employment, plant vintage and whether or not the firm was part of a larger group of companies. R\&D - undertaken by around 20.3 per cent of firms - is seen here as having two key roles: as a potential source of new knowledge for innovation but also as an indicator of firms' absorptive capacity, i.e. their ability to absorb external

\footnotetext{
${ }^{7}$ In principle it is possible that surveyed firms could themselves be part of the intra-regional linkages of other surveyed firms. However, given the low incidence of intra-regional connectivity, this is unlikely to bias the results.
} 
knowledge. In addition to the role of $R \& D$ as an element of absorptive capacity, we also include in the models a series of variables designed to reflect absorptive capacity $\left(A C A P_{i}\right)$ more directly. These include the level of graduate employment in the firm, investments in training specifically associated with firms' innovation activity as well as the level of investment for innovation. On average, around 5.5 per cent of the workforce of sample firms comprised science and engineering graduates with another 6.0 per cent being 'other' graduates (Table 1).

We also include in the models a number of other variables intended to capture aspects of firms' operating environment. The CIS provides information on perceived barriers to innovation $\left(B A R_{i}\right)^{8}$, with the most common - the 'costs of innovation' - being cited by 12.9 per cent of firms, the 'riskiness of innovation' (12.1 per cent) and the costs of finance (10.9 per cent). Market information effects (3.0 per cent) and the effects of regulation (7-8 per cent) and skill shortages (4.7 per cent) were less common barriers to innovation (Table 1). Binary indicators of whether firms have received government assistance for innovation from regional, national UK and international (EU) sources $\left(G O V T_{i}\right)$ are also provided by CIS. In each case we anticipate positive effects where such support has an additional effect. Finally, we include in each model a series of sectoral dummy variables to pick up sectoral differences in innovation activity and performance.

The IVC model outlined above is a development and extension to the CDM-type innovation production function models (e.g. Crépon et al., 1998). Models of this type are now widely used in empirical work on service innovation (Leiponen, 2005; Cainelli et al, 2006), and the IVC approach extends this to allow more explicitly for the effect of external knowledge sources. In particular, the IVC approach allows for the influence of, for example, absorptive capacity and firm-specific characteristics both indirectly via innovation (eq. 2) and directly in the performance equation (eq. 3).

An issue which arises in operationalising equation (3) is the potential endogeneity of the innovation output measures. This has been discussed extensively, and a range of

\footnotetext{
${ }^{8}$ In the CIS barriers to innovation were measured on a three-point scale indicating 'high', 'medium' or 'low' importance of each constraint. Here we transform these into dummy variables taking value ' 1 ' where a firm responded either 'medium' or 'high' and 0 otherwise.
} 
potential approaches have been adopted in the literature on manufacturing innovation including two-stage estimation methods (e.g. Crépon et al., 1998), and the simultaneous estimation of the innovation and augmented production functions (e.g. Lööf and Heshmati, 2002). In conceptual terms, however, the recursive nature of the innovation value chain suggests that innovation output measures are necessarily predetermined prior to their exploitation; in other words the innovation cannot be exploited until it has been introduced. In practical terms, this issue is dealt with in the present dataset by having performance measures (exporting and productivity) which post-date the period over which the innovation output indicators are measured.

\section{Determinants of Service Innovation}

The first step in modelling the innovation value chain is to identify the factors which determine service innovation. The results of estimating the innovation production function for different measures of innovation (i.e. equation 2) are shown in Tables 2 and 3. In Table 2 we estimate Probit models in which the dependent variables is a dummy variable for the five types of innovation: service, marketing, strategic advanced management techniques, and organisational change. These models reflect the factors which influence the extent of each type of innovation across the population of service sector firms. In Table 3 we report a Tobit model for the proportion of firms' sales derived from innovative products. This model reflects the factors which influence the success of firms' innovation activity. As we regard the estimation of both models as 'exploratory', rather than conforming to a well established theoretical framework, we adopt a broadly-based modelling strategy including a wide range of variables in the models to test significance. Models are clearly significant overall, however, and the measures of fit (pseudo $\mathrm{R}^{2}$ ) are comparable with other crosssectional studies ${ }^{9}$.

The first issue of interest in the innovation production functions is whether intraregional connectivity is significant in promoting innovation, an indication of the extent to which firms' innovation is driven by local knowledge inputs (Gertler, 2001). In fact, while the majority of intra-regional effects on innovation are insignificant,

\footnotetext{
${ }^{9}$ See for example Freel (2005), Tables 4 and 5 or Hewitt-Dundas (2006), Table 4.
} 
those which are significant at the 5 per cent level are always negative both in terms of the probability of innovating and innovation success. Links to local labs or consultants, for example, reduce the probability that firms will undertake service innovation by 5.7 per cent, while links to local customers reduce the probability of strategic innovation by 4.9 per cent and AMT innovation by 5.1 per cent (Table 2). The probability of undertaking organisational innovation is only impacted by local connectivity to suppliers customers (-6.1 per cent) and group members (-8.1 per cent). In terms of innovation success we also see negative local linkage effects, albeit only for links to local laboratories and consultants which reduce the proportion of innovative sales by 55.5 per cent (Table 3). In other words, for our data, the stronger are firms' intra-regional links, or the stronger their local embeddedness, the lower their probability of innovation and their innovation success.

By contrast, firms' extra-regional connectivity was seen to have some positive innovation effects, although extra-regional links to other group companies proved unimportant in terms of the probability of innovating (Table 2). Perhaps the most important of these results is the clear role of external customers in stimulating innovation activity. In fact, marginal values derived from the models suggest that a firm with links to external customers is $\mathbf{5 5 . 2}$ per cent more likely to undertake service innovation, 50.3 per cent more likely to undertake marketing innovation and 70.0 per cent more likely to undertake strategic innovation than firms without such links (Table 2). In addition, firms with external suppliers were also more likely to have a greater proportion (+37.8 per cent) of innovative sales than firms which were not selling outside the region (Table 3). A statistically insignificant positive effect on innovation success is also evident from innovation links to external customers (Table 3). Some smaller negative effects on the probability of innovating are associated with external connectivity, however: links to extra-regional laboratories and consultants on the probability of undertaking marketing innovation (-9.8 per cent), strategic innovation (-4.3 per cent) and AMT innovation (-5.7 per cent). In addition, extraregional links to universities have a strong negative effect on the probability of undertaking service innovation reducing it by 7.5 per cent.

These results, and in particular the contrast between the innovation benefits of intraand extra-regional connectivity, provide a relatively clear picture: intra-regional 
connectivity or embeddedness impacts negatively on service firms' innovation while extra-regional connectivity - particularly with external customers and suppliers - will stimulate innovation. This pattern accords closely with what (Boschma, 2005) describes as the 'neo-classical' view of embeddedness in which regional 'lock-in' is generated as local embeddedness limit firms' ability to generate variety in innovation ${ }^{10}$. The lack of any positive localised connectivity benefits for innovation also accords with other recent evidence for Ireland which suggests little innovation benefit from clustering among high-tech firms (Jordan and O’Leary, 2007).

In addition to connectivity, other basic characteristics of the firm also prove important in determining the probability that service firms in Northern Ireland will engage in innovation. R\&D is often said to be of less importance for service sector firms than for manufacturing businesses, but our results here emphasise its importance even in services: service firms undertaking $R \& D$ have a 26.4 per cent higher probability of undertaking service innovation, and an 11.1 per cent higher probability of undertaking marketing innovation (Table 2$)^{11}$. Firms undertaking R\&D also achieve significantly greater innovation success, increasing their average share of innovative products by 43.9 per cent (Table 3).

We also note positive links between the probability of innovating and firm size (Table 2), although there is no link between firm size and innovation success (Table 3). There is also a tendency for newer firms to be more likely to engage in strategic innovation (Table 2). Ownership also has a strong and consistently positive effect on the probability of undertaking innovation of all sorts, with firms which are part of a larger group more likely to innovate than independent firms (Table 2), and to have a larger proportion of innovative sales (Table 3). In general, however, these ownership effects are smaller than those for R\&D and links to external customers.

The estimation of our innovation equations also provides an opportunity to evaluate the impact of perceived barriers to innovation activity in Northern Ireland. In the models the effect of perceived barriers to innovation are generally weak - suggesting

\footnotetext{
${ }^{10}$ The opposing view outlined by (Boschma, 2005) is the 'agglomeration' view which stresses the informational advantages of spatial clustering.

${ }^{11}$ Notably, however, these effects are smaller than those associated with connectivity to external customers.
} 
little systematic impact - although there are some notable exceptions related to lack of qualified personnel, the availability of finance and the nature of the markets in which firms are operating. In particular firms perceiving a lack of qualified personnel were 20.2 per cent more likely to be undertaking organisational innovation, while those perceiving a lack of finance had greater average innovation success (Table 3). These effects are perhaps most likely to reflect the stronger perception of skills and finance barriers among innovation active firms rather than among non-innovators. Market conditions were more important in reducing the probability of service innovation with a perception that the market was dominated by established firms reducing the probability of undertaking service innovation by 8.7 per cent and a perception of an uncertain demand for innovation reducing service innovation by 6.8 per cent (Table 2). A perception that the market is dominated by external firms also reduced firms' percentage of innovative sales by 44.3 per cent.

Absorptive capacity relates to firms’ ability to absorb external knowledge and information and incorporate it into their innovation process (Zahra and George 2002). We find little support, however, for the assertion that firms' general capabilities in terms of graduate level skills positively influence innovation in services marketing or strategy (Table 2) or innovation success (Table 3). There are clearer positive effects on organisational innovation and firms' adoption of AMTs, although even here these effects are small in absolute terms (Table 2). Training for innovation and investment for innovation have more consistent positive effects on both the probability of innovating as well as innovation success (Tables 2 and 3). Perhaps the key contrast here in terms of our results on absorptive capacity is between the lack of any general capability effect on innovation - reflected in graduate skill levels - and the strong positive effect of more targeted initiatives by the firm - reflected in innovation related investments in training and capital equipment.

Methodological issues arise in considering the effect of government assistance on firms' innovation probability related to the possibility of selection effects (Greene, 2005). In particular, the coefficients on the policy support - treatment terms - reflect 
the combination of 'assistance' and 'selection' effects ${ }^{12}$. There is, however, little evidence of any very consistent positive effect on the probability of innovating for the whole group of service sector firms from either local, national or EU assistance. We do, however, find a positive effect from regional support on innovation success (Table 3).

\section{Innovation and Firm Performance}

\subsection{Exporting}

The next link in the innovation value chain is the relationship between innovation and aspects of business performance, measured by exporting and productivity. Here we look in detail at the impact of the different forms of innovation on three aspects of firms' export performance: first, whether the firm was or was not exporting outside Northern Ireland; second, export share, i.e. the proportion of exports in total sales in 2005 as reported in the $2005 \mathrm{ABI}$; and third, export growth, the percentage growth in the real value of export sales indicated by firms’ returns to the 2004 and 2005 ABI. In each case we allow for all five types of innovation identified earlier, and also allow for the effect of firm characteristics (e.g. size etc.), issues of absorptive capacity, and for sectoral differences in export performance. Correlation coefficients indicate a relatively low level of correlation between the various measures of innovation (see Annex). It should also be noted at the outset that the number of observations available for the export growth estimations is relatively small (c. 131 compared with 709 and 690 for exporter and export share respectively.). Results are obtained both for a service innovation dichotomous variable (Table 4), and for 'innovation success' i.e. the proportion of sales accounted for by services which were new or significantly improved during 2002-04 (Table 5).

The first notable result from our estimation is that we find no relationship between any aspect of firms' innovation behaviour over the 2002-04 period and whether or not a firm was an exporter in 2005: all of the coefficients in the models relating different types of innovation to firms' status as an exporter are insignificant at the 5 per cent level. Thus neither the act of innovating (Table 4) nor having a high proportion of

\footnotetext{
${ }^{12}$ Separately identifying the selection and assistance effects requires a different estimation approach to that adopted here. See (Maddala 1973), pp. 257-290 for a general discussion of the issue and Roper and Hewitt-Dundas (2001)for an application.
} 
new products in sales (Table 5) will make a firm become an exporter. More positively, however, firms undertaking organisational innovation do export a significantly larger proportion of their sales and have higher export growth (Tables 4 and 5). Innovation success also has a small positive effect on export growth (Table 5). Thus introducing new services will not turn non-exporters into exporters, but it will improve the export performance of those that are already exporters. On average, a $10 \%$ increase in the proportion of firms' sales coming from innovative products leads to a $6 \%$ increase in export growth the following year (Table 5). However, it is also the case that introducing a marketing innovation appears to have a significantly negative effect on export growth in the subsequent period (Table 4).

Other factors aside from innovation can, of course, also impact on service firms' exporting behaviour. However, firm characteristics and absorptive capacity measures have little consistent impact on exporting. The sectoral indicators are, however, highly significant with, for example, retail and hotel enterprises showing very low levels of exporting relative to the reference sector (Motor Trades).

\subsection{Productivity}

In this section we consider the relationship between innovation and productivity, another aspect of the final link in the innovation value chain. We use two measures of productivity: labour productivity (i.e. value added per employee) in 2005 as reported in the ABI; and labour productivity growth (i.e. real percentage growth) between 2004 and 2005, again as reported by firms in the 2004 and 2005 ABIs. The explanatory variables in the estimation of equation (3) are those used in the export estimation above, with the addition of a measure of capital intensity (capital investment per employee), and whether or not the firm was an exporter in 2004. As with exports, we show results both for a service innovation dichotomous variable (Table 6), and for 'innovation success' i.e. the proportion of sales accounted for by services which were new or significantly improved during 2002-04 (Table 7).

The results for innovation could not be clearer: once other factors are taken into account, there is no significant impact of innovation on firm productivity or productivity growth in the following year. At first sight this may appear to be something of a puzzle; while the introduction of new services might not have a 
positive productivity effect, and could even reduce productivity in the short term due to 'disruption effects', one might expect organisational or AMT innovations to have some effect on subsequent productivity. However, two points are relevant here. First, similar results have been found for the effect of innovation on business services in the United States (Mansury and Love, 2008), suggesting either that the lack of direct impact of service innovation on productivity is widespread, or that the impact of service innovation on productivity takes longer to manifest itself than the relatively short period under consideration in the present study. Second, our results indicate that there is a (weak) positive effect of R\&D on productivity, and a (stronger) R\&D effect on productivity growth. Firms with an $R \& D$ presence have rates of productivity growth 9 percentage points higher than those with no R\&D. Given the strong association between R\&D and virtually all forms of service innovation outlined earlier, this reinforces the role that in-house $R \& D$ can play even in a service context: R\&D underpins innovation, and thus ultimately encourages higher levels of productivity and productivity growth. Therefore rather than suggest that there is no link between service innovation and productivity, it might be more accurate to suggest that any such link is moderated at least partly through the positive impact of R\&D, either directly as a spur to innovation or indirectly as an element of firms’ absorptive capacity.

Other influences on productivity are much as might be expected (Tables 6 and 7). There is no clear association between firm size and productivity, although there is just a hint that smaller firms may have faster productivity growth than larger ones. New firms (established since 2000) are markedly less productive than older establishments, but have the same average rate of productivity growth. More capital intensive firms tend to have higher labour productivity, an almost universal finding in other studies. The sectoral indicators are in line with expectations: the retail and hotels sectors have very low labour productivity, while the productivity (and productivity growth) of a range of other sectors is significantly above that of the reference sector (Motor Trades).

\subsection{Innovation, $R \& D$, exporting and productivity}


So far we have looked separately at innovation and exporting, and at innovation and productivity. However, we must acknowledge that the relationships between innovation, exporting and productivity are intertwined in potentially complex ways that even the multivariate analysis above cannot fully unravel. For example, the relationship between productivity and exporting is potentially two-way: does exporting make firms more productive (because of learning effects and exposure to foreign competition), or do better performing firms simply choose to become exporters? There are sound reasons to expect exporting to enhance productivity, both through the exposure to foreign competition which exporting brings, and through 'learning by exporting', principally involving being exposed to superior foreign knowledge and technology. However, the broad thrust of previous research is that more productive firms self-select into export markets: there is mixed evidence on whether exporting leads to higher productivity thereafter, and very little research on services (see Wagner, 2007 for a comprehensive review).

In Tables 6 and 7 it is clear that being an exporter is associated with markedly greater productivity and productivity growth in the subsequent period. On average, an exporter in 2004 will have 10.8-10.9 percentage points faster productivity growth in the next year than a non-exporter. This does, of course, not rule out the possibility of a 'self-selection' effect which persists over time. However, although it is beyond the scope of the present dataset to explore fully the endogeneity between exporting and productivity $^{13}$, in some of our analysis (not reported) we included productivity as a variable in the exporting equations and found no effect, suggesting that the beneficial impact of exporting on productivity is real and, at least within the data structure considered here, unidirectional.

We can therefore draw some tentative conclusions about the link between innovation, exporting and productivity in the services sector. Although innovation appears to have no direct impact on productivity, and innovating will not turn a non-exporter into an exporter, innovation does have a positive impact on the extent and growth of exporting. At the same time, exporting is strongly associated with productivity, suggesting an indirect link between innovation and productivity via exporting. Earlier

\footnotetext{
${ }^{13}$ This requires a panel data set with a longer time series element. See Wagner (2007) for a recent review of the empirical evidence in this area.
} 
we also suggested that not only does R\&D have a direct effect on productivity, it also has an indirect effect through R\&D’s impact on innovation. A diagrammatic representation of these relationships between innovation, R\&D, exporting and productivity in services is given in Figure $1^{14}$. The crucial point is the indirect nature of the link between innovation and productivity (growth). Being an innovator assists exporting, and this in turn assists productivity. Both these effects are underpinned by $\mathrm{R} \& \mathrm{D}$, or at least a formal commitment to the innovation process. By itself, innovating is not enough: to derive productivity benefits from innovating, service firms need to look beyond sales in Northern Ireland. Innovation plus exporting is required for sustained productivity growth in services.

\section{Conclusions}

In this paper we have used a combined dataset from the 2005 UK Innovation Survey the UK element of the $4^{\text {th }}$ Community Innovation Survey - and the Annual Business Inquiry to explore the links between innovation, exporting and productivity in Northern Ireland services. The innovation value chain model suggests it is appropriate to consider these links in two main stages. First, we consider the determinants of service innovation, and secondly the effects of innovation on indicators of business performance.

A number of factors emerge as key drivers of service sector innovation in Northern Ireland. First, we find evidence of negative regional embeddedness effects, reflecting the possibility of regional lock-in suggested in the so-called 'neo-classical' view of embeddedness. Second - and also consistent with the 'neo-classical' embeddedness view - we find that extra-regional customers play a significant positive role in stimulating service, marketing, strategic and organisational innovation (Boschma 2005). Third, firms undertaking $R \& D$ have a 26.4 per cent increase in the probability of undertaking service innovation, and an 11.1 per cent increase in the chance of undertaking marketing innovation. This result contrasts with the conventional wisdom

\footnotetext{
${ }^{14}$ This figure does not purport to be a complete description of every part the process. For example, there will be significant sectoral variations in the nature and strength of these relationships, as indicated by the shaded box and dotted lines. Figure 1 should therefore be interpreted as providing a high-level overview of how R\&D, innovation and exporting interact to affect firm-level productivity in services in Northern Ireland, based on the econometric analysis outlined above.
} 
that $R \& D$ is less important in service innovation than in manufacturing, but might reflect the role of $R \& D$ as an element of absorptive capacity rather than as a knowledge generator per se. Fourth, the probability of innovating is also positively related to firm size and newness, and ownership also has a strong and consistently positive effect on innovation of all sorts, with firms which are part of a larger group more likely to innovate than independent firms. Fifth, factor shortages or access to finance are not significant barriers to service innovation in Northern Ireland, instead it is demand-side, market related factors that dominate firms' innovation decisions. Finally, we find little support for the positive impact of focussed support for innovation but there is clear evidence that specific interventions intended to either develop skills or the capital basis for innovation have consistent positive effects on the probability of undertaking all forms of innovation. This is likely to reflect the more widespread availability of such support for services firms in Northern Ireland than more focussed innovation support.

Our analysis of the links between innovation, regional exporting and productivity suggest that the relationships are complex. Undertaking innovation is not sufficient to turn a non-exporting service firm into an exporter; however, innovating does have a positive impact on the extent and growth of exporting. Innovation has no direct impact on productivity but does have a strong indirect effect on productivity through its impacts on the extent and growth of exports. On average, an exporter in 2004 will have 11 percentage point faster productivity growth in the next year than a nonexporter. At the same time, exporting is strongly associated with productivity, suggesting an indirect link between innovation and productivity via exporting. Earlier we also suggested that not only does R\&D have a direct effect on service productivity, it also has an indirect effect through R\&D’s impact on innovation. Overall, we conclude therefore that both innovation and exporting are required for sustained regional productivity growth in services, and that both are underpinned by firms’ R\&D activity.

In terms of regional innovation, our results suggest the greater value of extra-regional linkages to customers rather than intra-regional linkages to any sort of other organisation. This appears to runs somewhat contrary to the literature on regional innovation systems which tends to emphasise local linkages or 'associations' as a 
driver of effective innovation (e.g. Cooke and Morgan, 1998), and instead perhaps suggests the 'weakness of strong ties’ emphasised by Grabher (1993). In fact, however, as the descriptives in Table 1 suggest, only a very small proportion (c. 3-5 per cent) of Northern Ireland services firms had either intra-regional or extra-regional linkages as part of their innovation activity. The relative scarcity of intra-regional innovation linkages in Northern Ireland weakens any suggestion that these local linkages are an important determinant of firms' development trajectories and may be contributing significantly to 'lock-in'. What is clear, however, from our evidence is that Northern Ireland firms' current profile of intra-regional linkages is contributing little to their innovation outputs, while links to external customers are more positive.

In policy terms this suggests that in regions like Northern Ireland measures to promote innovation should prioritise the development of collaborative innovation projects with extra-regional customers. One possible policy model is the Israel-US BIRD foundation through which Israeli and US firms are supported to work on joint R\&D or innovation projects aimed at US or international markets ${ }^{15}$. Grabher (1993) and the literature on regional innovation systems - also suggest the potential value for innovation of developing new intra-regional innovation linkages. These, it is argued, may provide new ideas as well as the basis for collaborative development. Given the weakness of intra-regional innovation linkages in Northern Ireland at present this also seems a reasonable policy focus particularly as studies such as Bilbao-Osorio and Rodriquez-Pose (2004) have emphasised the importance of the 'learning' - or knowledge sharing - capability of regions in maximising the regional impact of R\&D spending. Our study also provides evidence that other investments which may support service firms' learning capabilities or absorptive capacity are also important for innovation, i.e. R\&D investment, and training and capital investment for innovation.

More generally, our results suggest that innovation itself is not sufficient to generate improvements in regional productivity as the 'Five Drivers' might suggest (H M Treasury 2000). Instead, for Northern Ireland services firms, the productivity benefits of innovation are contingent on the development of firms' export activity. One potential explanation is linked to economies of scale, where the potential productivity

\footnotetext{
${ }^{15}$ See http://www.birdf.com.
} 
impact of newly introduced services are only achieved when firms begin to trade in external markets as well as the relatively small Northern Ireland home market. In policy terms this suggests the need for an approach which focuses on developing both firms' innovation and internationalisation capabilities. Of course, as our results also suggest that links to extra-regional customers tend also to boost firms' innovation activity these developments in capability should be mutually reinforcing (see also Wolff and Pett, 2006).

As indicated earlier Northern Ireland shares may characteristics with other peripheral regions in terms of its on-going restructuring, the increasing importance of services in regional growth and its relatively small home market. This suggests that our main results - particularly perhaps the contingent impact of innovation and exporting on productivity - should be more generally applicable. For firms located in the Western Balkans, for example, where local services markets are often under-developed, innovation is also likely to be strongly dependent on, and reinforced by, export market orientation. Similarly, innovation and exporting are likely to play a reinforcing role in capability development and growth for firms in developing economies (e.g. Robson and Freel, 2008). Some key questions remain, however, about the most beneficial forms of export customer interaction for innovation as well as the design of effective policy supports. Both issues are likely to require an extension of the current analysis to other regions and perhaps a more in-depth approach than that adopted here focussing on individual firm's development of their internationalisation and innovation capabilities. 
Table 1: Descriptive Statistics

n

Mean

Std. Dev

\section{Innovation Measures}

Service Innovation

Marketing Innovation

Strategic Innovation

AMT Innovation

Organisational Innovation

Innovation Success

$\begin{array}{llr}768 & 0.147 & 0.355 \\ 767 & 0.163 & 0.369 \\ 767 & 0.125 & 0.331 \\ 766 & 0.127 & 0.333 \\ 767 & 0.138 & 0.345 \\ 773 & 7.004 & 20.355\end{array}$

\section{Performance Measures}

Exporter

773

0.342

0.474

Exports as share of sales (2005, \%)

700

1.730

6.068

Export growth 2004-05 (\%)

166

$-0.235$

1.608

GVA per employee (2005

698

28.570

39.667

GVA growth per employee (2005)

683

0.066

0.519

\section{Intra-regional Connectivity}

Local group members

Local suppliers

773

0.023

0.151

Local customers

773

0.034

0.181

Local competitors

773

0.023

0.150

Local laboratories, consultants

773

0.014

0.117

Local universities

773

0.018

0.133

\section{Extra-regional Connectivity}

External group members

External suppliers

External customers

External competitors

External labs, consultants

External universities

\section{Firm characteristics}

Research and Development

Employment (2002, nos)

Firm established post 2000

Part of larger group

768

0.214

0.410

Perceived barriers to innovation

Riskiness of innovation 
Costs of finance

Availability of finance

Lack of qualified personnel

Lack of info on markets

Market dominated by established firms

Uncertain demand for innovation

Need to meet UK regulations

Need to meet EU regulations
773

773

773

773

773

773

773

773

\section{Absorptive Capacity}

Science and Eng graduates

Other graduates

Training for innovation

Investment for innovation

\section{Government Assistance}

Local or regional

UK national

EU assistance

\section{Sectoral Indicators}

Motor Trades

Wholesale

Retail

Hotels and hospitality

Transport and Communications

Financial services

Real estate, renting

Computer services, $R \& D$

Other Business Services
773

773

769

769

766

766

762

0.063

0.056

0.006

5.464

0.333

0.397

0.089

0.122

0.243

0.223

0.074

0.032

0.041

0.037

0.139
0.312

0.281

0.212

0.169

0.221

0.210

0.269

0.250

16.656

13.351

0.471

0.489

Notes: Observations relate to private services sector and are weighted to give regionally representative results.

Sources: UK Innovation Survey 2005 (UK element of the $4^{\text {th }}$ Community Innovation Survey), Annual Business Inquiry, 2004 and 2005. 
Table 2: Determinants of Service Innovation in Northern Ireland: Marginal Effects from Probit Models

\begin{tabular}{|c|c|c|c|c|c|c|c|c|c|c|c|c|c|c|c|}
\hline & \multicolumn{3}{|c|}{ Service Innovation } & \multicolumn{3}{|c|}{ Marketing Innovation } & \multicolumn{3}{|c|}{ Strategic Innovation } & \multicolumn{3}{|c|}{ ATM Innovation } & \multicolumn{3}{|c|}{ Organisational Innovation } \\
\hline & $\mathrm{dy} / \mathrm{dx}$ & $\mathrm{t}$ stat & & $\mathrm{dy} / \mathrm{dx}$ & $\mathrm{t}$ stat & & $\mathrm{dy} / \mathrm{dx}$ & $\mathrm{t}$ stat & & $\mathrm{dy} / \mathrm{dx}$ & $\mathrm{t}$ stat & & $\mathrm{dy} / \mathrm{dx}$ & t stat & \\
\hline \multicolumn{16}{|l|}{ Intra-regional Connectivity } \\
\hline Local group members & 0.227 & 1.33 & & -0.002 & -0.02 & & -0.023 & -0.80 & & -0.036 & -1.18 & & -0.081 & -5.77 & $* * *$ \\
\hline Local suppliers & -0.024 & -0.38 & & -0.018 & -0.23 & & 0.137 & 1.01 & & 0.006 & 0.09 & & -0.061 & -2.14 & $* *$ \\
\hline Local customers & 0.005 & 0.07 & & -0.044 & -0.79 & & -0.049 & -3.95 & $* * *$ & -0.051 & -3.14 & $* * *$ & 0.071 & 0.68 & \\
\hline Local competitors & 0.07 & 0.56 & & 0.032 & 0.33 & & 0.09 & 0.82 & & -0.035 & -1.17 & & -0.01 & -0.14 & \\
\hline Local laboratories, consultants & -0.057 & -1.83 & * & 0.164 & 0.75 & & 0.093 & 0.62 & & 0.411 & 1.33 & & 0.331 & 1.42 & \\
\hline Local universities & 0.046 & 0.46 & & 0.052 & 0.41 & & -0.006 & -0.13 & & 0.178 & 0.91 & & 0.036 & 0.35 & \\
\hline \multicolumn{16}{|l|}{ Extra-regional Connectivity } \\
\hline External group members & 0.044 & 0.36 & & 0.046 & 0.25 & & 0.015 & 0.16 & & -0.035 & -0.69 & & 0.17 & 0.73 & \\
\hline External suppliers & 0.101 & 0.84 & & 0.015 & 0.14 & & 0.023 & 0.34 & & 0.078 & 0.61 & & -0.073 & -4.06 & $* * *$ \\
\hline External customers & 0.552 & 2.63 & $* * *$ & 0.503 & 2.61 & $* * *$ & 0.179 & 1.20 & & 0.175 & 1.24 & & 0.7 & 4.20 & $* * *$ \\
\hline External competitors & -0.052 & -1.57 & & 0.243 & 0.93 & & 0.122 & 1.05 & & 0.626 & 2.28 & ** & 0.094 & 0.60 & \\
\hline External labs, consultants & -0.013 & -0.15 & & -0.098 & -5.14 & $* * *$ & -0.043 & -3.32 & $* * *$ & -0.057 & -4.33 & $* * *$ & 0.024 & 0.19 & \\
\hline External universities & -0.075 & -5.03 & $* * *$ & 0.04 & 0.22 & & 0.009 & 0.11 & & 0.03 & 0.23 & & -0.044 & -0.74 & \\
\hline \multicolumn{16}{|l|}{ Firm characteristics } \\
\hline Research and Development & 0.264 & 3.56 & $* * *$ & 0.111 & 2.28 & ** & 0.019 & 0.86 & & 0.036 & 1.30 & & -0.03 & -1.12 & \\
\hline Employment (2002, nos) & 0 & 0.06 & & 0 & 1.60 & & 0 & 2.76 & $* * *$ & 0 & 1.95 & $*$ & 0 & 1.34 & \\
\hline Employment squared & 0 & 0.22 & & 0 & -1.03 & & 0 & -2.44 & $* *$ & 0 & -0.62 & & 0 & -0.43 & \\
\hline Firm established post 2000 & 0.053 & 1.24 & & -0.032 & -0.95 & & 0.09 & 2.56 & $* *$ & -0.018 & -0.78 & & 0 & 0.01 & \\
\hline Part of larger group & 0.082 & 2.33 & $* *$ & 0.091 & 2.32 & $* *$ & 0.14 & 3.28 & $* * *$ & 0.076 & 2.64 & $* * *$ & 0.202 & 4.23 & **** \\
\hline \multicolumn{16}{|l|}{ Perceived barriers to innovation } \\
\hline Riskiness of innovation & 0.128 & 1.57 & & 0.086 & 1.26 & & 0.06 & 1.24 & & 0.067 & 1.26 & & 0.071 & 1.17 & \\
\hline Costs of innovation & -0.049 & -1.58 & & -0.013 & -0.29 & & -0.003 & -0.12 & & 0.014 & 0.35 & & 0.01 & 0.21 & \\
\hline Costs of finance & -0.037 & -1.07 & & -0.051 & -1.24 & & -0.021 & -0.92 & & -0.014 & -0.45 & & 0.015 & 0.29 & \\
\hline Availability of finance & 0.072 & 1.00 & & 0.081 & 1.01 & & 0.021 & 0.56 & & 0.005 & 0.13 & & 0.022 & 0.40 & \\
\hline Lack of qualified personnel & 0.075 & 0.92 & & 0.165 & 1.58 & & 0.053 & 0.93 & & 0.043 & 0.79 & & 0.202 & 1.98 & ** \\
\hline Lack of info on markets & 0 & 0.00 & & 0.134 & 0.91 & & 0.09 & 0.88 & & 0.08 & 0.78 & & 0.128 & 1.06 & \\
\hline Market dominated by established firms & -0.087 & -5.16 & $* * *$ & 0.001 & 0.01 & & -0.022 & -0.86 & & -0.04 & -1.85 & * & -0.018 & -0.42 & \\
\hline Uncertain demand for innovation & -0.068 & -3.09 & $* * *$ & 0.025 & 0.34 & & -0.024 & -1.14 & & 0.093 & 1.30 & & 0.027 & 0.52 & \\
\hline Need to meet UK regulations & -0.061 & -1.77 & * & -0.005 & -0.06 & & -0.037 & -1.58 & & -0.005 & -0.10 & & 0.025 & 0.33 & \\
\hline
\end{tabular}




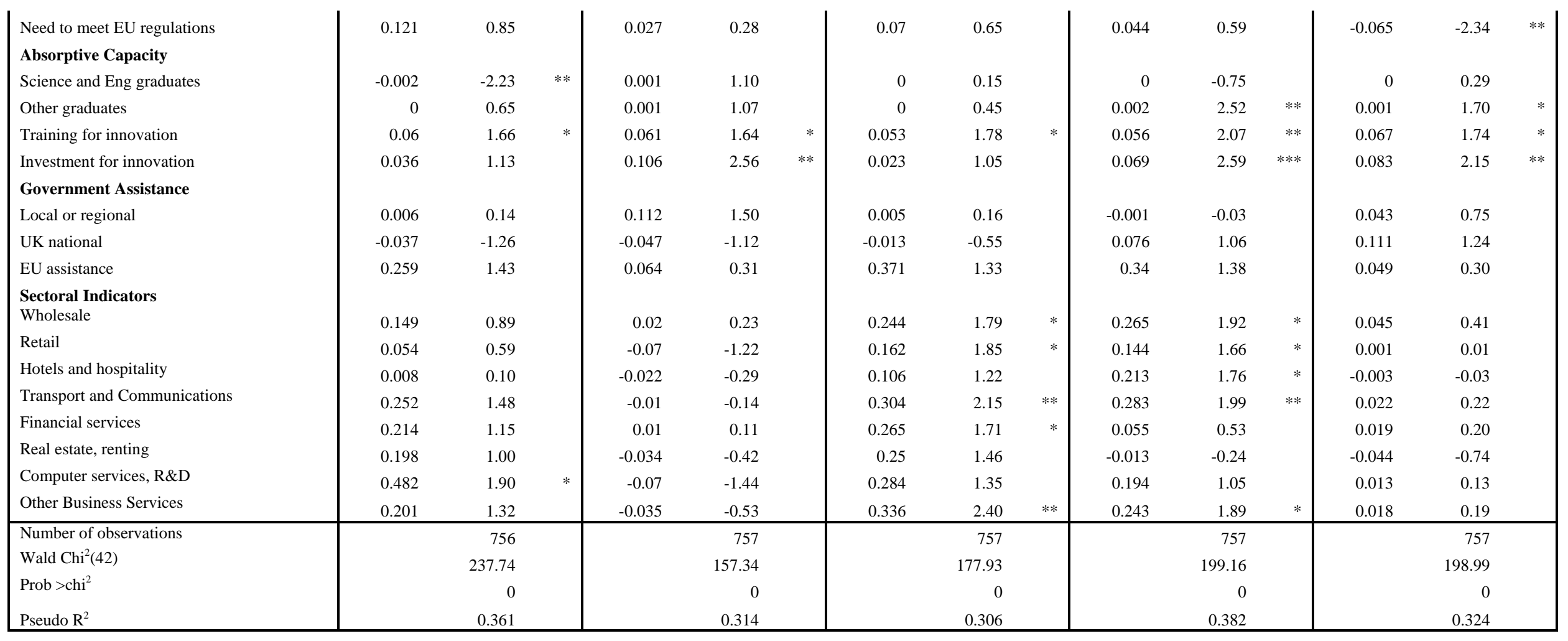

Notes: Observations are weighted to give regionally representative results. * denotes significance at 10 per cent level; ** significant at 5 per cent level and *** significant at 1 per cent level.

Sources: UK Innovation Survey 2005 (UK element of the $4^{\text {th }}$ Community Innovation Survey). 
Table 3: Tobit Model of Innovation Success (\% sales) - marginal effects

\begin{tabular}{|c|c|c|c|}
\hline & $\mathrm{dy} / \mathrm{dx}$ & t-stat & \\
\hline \multicolumn{4}{|l|}{ Local Connectivity } \\
\hline Local group members & 27.964 & 1.18 & \\
\hline Local suppliers & 16.897 & 0.66 & \\
\hline Local customers & 2.007 & 0.09 & \\
\hline Local competitors & 21.344 & 0.78 & \\
\hline Local laboratories, consultants & -55.582 & -1.98 & $* *$ \\
\hline Local universities & 14.839 & 0.60 & \\
\hline \multicolumn{4}{|l|}{ External Connectivity } \\
\hline External group members & 35.705 & 1.15 & \\
\hline External suppliers & 37.803 & 1.69 & * \\
\hline External customers & 24.291 & 0.95 & \\
\hline External competitors & -14.546 & -0.57 & \\
\hline External labs, consultants & -65.293 & -1.92 & $*$ \\
\hline External universities & -23.398 & -0.70 & \\
\hline \multicolumn{4}{|l|}{ Firm characteristics } \\
\hline Research and Development & 43.937 & 4.70 & $* * *$ \\
\hline Employment (2002, nos) & 0.002 & 0.22 & \\
\hline Employment squared & 0 & -0.13 & \\
\hline Firm established post 2000 & 11.099 & 1.13 & \\
\hline Part of larger group & 19.549 & 2.51 & $* *$ \\
\hline \multicolumn{4}{|l|}{ Perceived barriers to innov. } \\
\hline Riskiness of innovation & 11.979 & 0.92 & \\
\hline Costs of innovation & -11.067 & -0.81 & \\
\hline Costs of finance & -13.696 & -0.96 & \\
\hline Availability of finance & 26.077 & 1.81 & $*$ \\
\hline Lack of qualified personnel & 5.479 & 0.33 & \\
\hline Lack of info on markets & 22.424 & 1.00 & \\
\hline Market dominated by established firms & -44.275 & -2.21 & $* *$ \\
\hline Uncertain demand for innovation & -1.701 & -0.10 & \\
\hline Need to meet UK regulations & -26.415 & -1.23 & \\
\hline Need to meet EU regulations & 4.162 & 0.17 & \\
\hline \multicolumn{4}{|l|}{ Absorptive Capacity } \\
\hline Science and Eng graduates & -0.376 & -1.47 & \\
\hline Other graduates & 0.031 & 0.13 & \\
\hline Training for innovation & 26.239 & 2.91 & $* * *$ \\
\hline Investment for innovation & 14.84 & 1.67 & * \\
\hline \multicolumn{4}{|l|}{ Government Assistance } \\
\hline Local or regional & 30.067 & 2.10 & $* *$ \\
\hline UK national & -7.139 & -0.44 & \\
\hline EU assistance & 43.769 & 1.53 & \\
\hline \multicolumn{4}{|l|}{ Sectoral Indicators } \\
\hline Wholesale & -0.816 & -0.04 & \\
\hline Retail & -8.384 & -0.47 & \\
\hline Hotels and hospitality & -6.547 & -0.34 & \\
\hline Transport and Communications & 15.036 & 0.79 & \\
\hline Financial services & 25.972 & 1.24 & \\
\hline Real estate, renting & -11.252 & -0.39 & \\
\hline Computer services, R\&D & 56.781 & 2.09 & ** \\
\hline
\end{tabular}




\begin{tabular}{|l|r|} 
& 13.808 \\
\hline Other Business Services & 0.73 \\
\hline Wamber of observations & \\
Prob $>$ chi $^{2}$ & 757 \\
Pseudo ${ }^{2}$ & 195.56 \\
\end{tabular}

Notes: Observations are weighted to give regionally representative results. * denotes significance at 10 per cent level; ${ }^{* *}$ significant at 5 per cent level and ${ }^{* * *}$ significant at 1 per cent level.

Sources: UK Innovation Survey 2005 (UK element of the $4^{\text {th }}$ Community Innovation Survey). 
Table 4: Estimations of Export Performance: Service innovation (marginal effects)

\begin{tabular}{|c|c|c|c|c|c|c|c|c|c|}
\hline & \multicolumn{3}{|c|}{ Exporter } & \multicolumn{3}{|c|}{ Export Share } & \multicolumn{3}{|c|}{ Export Growth } \\
\hline & Coeff. & \multicolumn{2}{|l|}{ t-stat. } & Coeff. & \multicolumn{2}{|l|}{ t-stat. } & Coeff. & \multicolumn{2}{|l|}{ t-stat. } \\
\hline \multicolumn{10}{|l|}{ Innovation } \\
\hline Service Innovation & -0.001 & -0.01 & & 2.43 & 1.32 & & 0.154 & 0.98 & \\
\hline Marketing Innovation & -0.055 & -0.82 & & -3.238 & -1.53 & & -0.514 & -2.57 & ** \\
\hline Strategic Innovation & -0.007 & -0.09 & & -2.019 & -0.92 & & 0.167 & 0.83 & \\
\hline AMT Innovation & 0.047 & 0.57 & & 1.222 & 0.58 & & -0.246 & -1.24 & \\
\hline Organisational Innovation & 0.119 & 1.30 & & 4.603 & 2.09 & ** & 0.46 & 2.10 & ** \\
\hline \multicolumn{10}{|l|}{ Firm characteristics } \\
\hline Research and Development & 0.073 & 1.10 & & 1.238 & 0.66 & & 0.368 & 1.59 & \\
\hline Employment (2002, nos) & 0 & -0.45 & & -0.002 & -1.05 & & 0.003 & 1.47 & \\
\hline Employment squared & 0 & 1.07 & & 0 & 1.22 & & 0 & -1.48 & \\
\hline Firm established post 2000 & -0.046 & -0.76 & & 0.673 & 0.37 & & 0.11 & 0.52 & \\
\hline Part of larger group & -0.081 & -1.53 & & -2.356 & -1.58 & & -0.227 & -1.33 & \\
\hline \multicolumn{10}{|l|}{ Absorptive Capacity } \\
\hline Science and Eng graduates & 0.003 & 1.68 & * & 0.073 & 1.71 & * & -0.01 & -3.04 & *** \\
\hline Other graduates & 0 & 0.15 & & -0.015 & -0.31 & & 0.003 & 0.66 & \\
\hline Training for innovation & -0.15 & -2.83 & $* * *$ & -1.841 & -1.12 & & 0.033 & 0.15 & \\
\hline Investment for innovation & 0.009 & 0.16 & & 1.862 & 1.21 & & 0.142 & 0.75 & \\
\hline \multicolumn{10}{|l|}{ Sectoral Indicators } \\
\hline Wholesale & 0.078 & 0.61 & & 2.486 & 0.82 & & 0.223 & 0.20 & \\
\hline Retail & -0.182 & -2.42 & ** & -4.284 & -1.56 & & 0.023 & 0.02 & \\
\hline Hotels and hospitality & -0.35 & -6.38 & $* * *$ & -21.022 & -3.90 & *** & -0.144 & -0.14 & \\
\hline \multicolumn{10}{|l|}{ Transport and } \\
\hline Communications & 0.357 & 3.11 & *** & 7.361 & 2.58 & $* * *$ & -0.167 & -0.15 & \\
\hline \multicolumn{10}{|l|}{ Financial services } \\
\hline \multirow{3}{*}{$\begin{array}{l}\text { Real estate, renting } \\
\text { Computer services, R\&D } \\
\text { Other Business Services }\end{array}$} & 0.173 & 1.15 & & 1.744 & 0.44 & & -0.128 & -0.11 & \\
\hline & 0.571 & 3.87 & $* * *$ & 16.354 & 3.79 & $* * *$ & -0.055 & -0.05 & \\
\hline & 0.214 & 1.77 & * & 6.306 & 2.15 & $* *$ & -0.302 & -0.27 & \\
\hline \multirow{5}{*}{$\begin{array}{l}\text { Estimation } \\
\text { Wald Chi-squared (12) } \\
\text { LR Chi-squared (22) } \\
\text { (Pseudo) R² } \\
\text { Observations }\end{array}$} & \multirow{2}{*}{\multicolumn{3}{|c|}{$\begin{array}{c}\text { Probit } \\
248.2\end{array}$}} & \multirow{2}{*}{\multicolumn{2}{|c|}{ Tobit }} & & \multicolumn{2}{|c|}{ OLS } & \\
\hline & & & & & & & & & \\
\hline & & \multicolumn{3}{|c|}{203.86} & \multirow{2}{*}{\multicolumn{3}{|c|}{0.187}} \\
\hline & \multirow{2}{*}{\multicolumn{3}{|c|}{$\begin{array}{c}0.286 \\
709\end{array}$}} & \multicolumn{3}{|c|}{0.091} & & & \\
\hline & & & & \multicolumn{3}{|c|}{690} & \multicolumn{2}{|c|}{131} & \\
\hline
\end{tabular}

Notes: Observations are weighted to give regionally representative results. * denotes significance at 10 per cent level; ** significant at 5 per cent level and ${ }^{* * *}$ significant at 1 per cent level.

Sources: UK Innovation Survey 2005, Annual Business Inquiry, 2004 and 2005. 
Table 5: Estimations of Export Performance: Innovation success (marginal effects)

\begin{tabular}{|c|c|c|c|c|c|c|c|c|}
\hline & \multicolumn{3}{|c|}{ Exporter } & \multicolumn{3}{|c|}{ Export Share } & \multicolumn{2}{|c|}{ Export Growth } \\
\hline & Coeff. & t-stat. & & Coeff. & t-stat. & & Coeff. & t-stat. \\
\hline \multicolumn{9}{|l|}{ Innovation } \\
\hline Innovation Success & -0.002 & -1.74 & * & 0.018 & 0.53 & & 0.006 & 1.98 \\
\hline Marketing Innovation & -0.042 & -0.60 & & -3.072 & -1.45 & & -0.555 & -2.76 \\
\hline Strategic Innovation & 0.007 & 0.08 & & -1.932 & -0.87 & & 0.117 & 0.58 \\
\hline AMT Innovation & 0.054 & 0.65 & & 1.333 & 0.63 & & -0.234 & -1.14 \\
\hline Organisational Innovation & 0.122 & 1.35 & & 4.585 & 2.07 & $* *$ & 0.404 & 1.81 \\
\hline \multicolumn{9}{|l|}{ Firm characteristics } \\
\hline Research and Development & 0.082 & 1.26 & & 1.751 & 0.95 & & 0.331 & 1.39 \\
\hline Employment (2002, nos) & 0 & -0.48 & & -0.002 & -1.01 & & 0.003 & 1.43 \\
\hline Employment squared & 0 & 1.09 & & 0 & 1.18 & & 0 & -1.43 \\
\hline Firm established post 2000 & -0.043 & -0.70 & & 0.529 & 0.29 & & 0.034 & 0.17 \\
\hline Part of larger group & -0.082 & -1.57 & & -2.171 & -1.45 & & -0.165 & -1.00 \\
\hline \multicolumn{9}{|l|}{ Absorptive Capacity } \\
\hline Science and Eng graduates & 0.002 & 1.56 & & 0.067 & 1.58 & & -0.01 & -3.25 \\
\hline Other graduates & 0 & 0.21 & & -0.015 & -0.32 & & 0.004 & 0.91 \\
\hline Training for innovation & -0.136 & -2.58 & $* * *$ & -1.71 & -1.04 & & 0.125 & 0.57 \\
\hline Investment for innovation & 0.01 & 0.17 & & 1.941 & 1.26 & & 0.084 & 0.45 \\
\hline \multicolumn{9}{|l|}{ Sectoral Indicators } \\
\hline Wholesale & 0.071 & 0.56 & & 2.44 & 0.80 & & 0.259 & 0.23 \\
\hline Retail & -0.187 & -2.50 & ** & -4.251 & -1.54 & & 0.06 & 0.05 \\
\hline Hotels and hospitality & -0.351 & -6.47 & $* * *$ & -20.817 & -3.91 & $* * *$ & -0.321 & -0.31 \\
\hline Transport and Communications & 0.357 & 3.11 & $* * *$ & 7.713 & 2.71 & $* * *$ & -0.16 & -0.14 \\
\hline Financial services & & & & 10.982 & 0.89 & & & \\
\hline Real estate, renting & 0.168 & 1.12 & & 1.957 & 0.49 & & -0.055 & -0.05 \\
\hline Computer services, R\&D & 0.595 & 4.24 & $* * *$ & 16.734 & 3.86 & $* * *$ & -0.163 & -0.15 \\
\hline Other Business Services & 0.211 & 1.75 & * & 6.65 & 2.27 & ** & -0.248 & -0.22 \\
\hline Estimation & \multirow{2}{*}{\multicolumn{3}{|c|}{$\begin{array}{l}\text { Probit } \\
172.89\end{array}$}} & \multirow{2}{*}{\multicolumn{3}{|c|}{ Tobit }} & \multicolumn{2}{|c|}{ OLS } \\
\hline Wald Chi-squared (12) & & & & & & & & \\
\hline LR Chi-squared (22) & & \multicolumn{3}{|c|}{202.77} & & \\
\hline (Pseudo) R² & \multicolumn{3}{|c|}{0.289} & \multicolumn{3}{|c|}{0.09} & \multicolumn{2}{|c|}{0.2} \\
\hline Observations & \multicolumn{3}{|c|}{710} & \multicolumn{3}{|c|}{691} & \multicolumn{2}{|c|}{131} \\
\hline
\end{tabular}

Notes: Observations are weighted to give regionally representative results. * denotes significance at 10 per cent level; ${ }^{* *}$ significant at 5 per cent level and ${ }^{* * *}$ significant at 1 per cent level.

Sources: UK Innovation Survey 2005, Annual Business Inquiry, 2004 and 2005. 
Table 6: Estimations of Productivity: Service innovation

\begin{tabular}{|c|c|c|c|c|c|c|}
\hline & Produc & $y(2005)$ & & Productiv & Growth & \\
\hline & Coeff. & t-stat & & Coeff. & t-stat & \\
\hline Innovation & & & & & & \\
\hline Service Innovation & -0.002 & 0.00 & & -0.023 & -0.54 & \\
\hline Marketing Innovation & -2.749 & -1.57 & & -0.023 & -0.50 & \\
\hline Strategic Innovation & 0.361 & 0.19 & & 0.017 & 0.37 & \\
\hline AMT Innovation & -0.682 & -0.34 & & -0.019 & -0.40 & \\
\hline Organisational Innovation & 2.957 & 1.51 & & 0.014 & 0.29 & \\
\hline Firm characteristics & & & & & & \\
\hline Research and Development & 2.341 & 1.61 & & 0.095 & 2.51 & ** \\
\hline Employment (2002, nos) & -0.007 & -1.75 & * & 0 & -0.79 & \\
\hline Employment squared & 0.001 & 1.49 & & 0 & 1.20 & \\
\hline Firm established post 2000 & -3.355 & -3.06 & *** & 0.002 & 0.04 & \\
\hline Part of larger group & 0.734 & 0.53 & & -0.042 & -1.16 & \\
\hline Capital intensity & 0.151 & 2.19 & ** & -0.002 & -1.11 & \\
\hline Exporter (2004) & 10.246 & 6.33 & $* * *$ & 0.109 & 3.10 & *** \\
\hline Absorptive Capacity & & & & & & \\
\hline Science and Eng graduates & 0.012 & 0.26 & & 0.001 & 0.73 & \\
\hline Other graduates & 0.052 & 1.29 & & -0.001 & -0.91 & \\
\hline Training for innovation & -2.078 & -1.62 & & -0.051 & -1.47 & \\
\hline Investment for innovation & 1.134 & 0.89 & & 0.043 & 1.12 & \\
\hline Sectoral Indicators & & & & & & \\
\hline Wholesale & 1.068 & 0.34 & & -0.016 & -0.19 & \\
\hline Retail & -5.157 & -2.39 & ** & -0.029 & -0.41 & \\
\hline Hotels and hospitality & -10.462 & -4.74 & $* * *$ & -0.028 & -0.38 & \\
\hline Transport and Communications & 2.86 & 1.13 & & -0.072 & -1.10 & \\
\hline Financial services & 14.253 & 3.17 & $* * *$ & 0.161 & 1.86 & * \\
\hline Real estate, renting & 9.621 & 1.97 & $* *$ & 0.002 & 0.02 & \\
\hline Computer services, R\&D & 4.657 & 1.59 & & -0.022 & -0.32 & \\
\hline Other Business Services & 21.708 & 9.87 & *** & 0.034 & 0.49 & \\
\hline Estimation & OLS & & & OLS & & \\
\hline$F(.,)$. & 30.16 & & & 2.67 & & \\
\hline $\mathrm{R}^{2}$ & 0.542 & & & 0.094 & & \\
\hline Observations & 650 & & & 542 & & \\
\hline
\end{tabular}

Notes: Observations are weighted to give regionally representative results. * denotes significance at 10 per cent level; ** significant at 5 per cent level and ${ }^{* * *}$ significant at 1 per cent level.

Sources: UK Innovation Survey 2005, Annual Business Inquiry, 2004 and 2005. 
Table 7: Estimations of Productivity: Innovation success

\begin{tabular}{|c|c|c|c|c|c|c|}
\hline & \multicolumn{3}{|c|}{ Productivity (2005) } & \multicolumn{3}{|c|}{ Productivity Growth } \\
\hline & Coeff. & t-stat & & Coeff. & t-stat & \\
\hline \multicolumn{7}{|l|}{ Innovation } \\
\hline Innovation Success & -0.015 & -0.48 & & 0 & -0.20 & \\
\hline Marketing Innovation & -2.634 & -1.49 & & -0.024 & -0.53 & \\
\hline Strategic Innovation & 0.411 & 0.22 & & 0.015 & 0.33 & \\
\hline AMT Innovation & -0.609 & -0.31 & & -0.02 & -0.43 & \\
\hline Organisational Innovation & 2.993 & 1.54 & & 0.015 & 0.31 & \\
\hline \multicolumn{7}{|l|}{ Firm characteristics } \\
\hline Research and Development & 2.443 & 1.68 & * & 0.092 & 2.45 & $* *$ \\
\hline Employment (2002, nos) & -0.007 & -1.76 & * & 0 & -0.78 & \\
\hline Employment squared & 0.001 & 1.49 & & 0 & 1.19 & \\
\hline Firm established post 2000 & -3.304 & -3.08 & $* * *$ & 0.002 & 0.05 & \\
\hline Part of larger group & 0.697 & 0.51 & & -0.043 & -1.20 & \\
\hline Capital intensity & 0.152 & 2.20 & $* *$ & -0.002 & -1.09 & \\
\hline Exporter (2004) & 10.27 & 6.36 & $* * *$ & 0.108 & 3.09 & $* * *$ \\
\hline \multicolumn{7}{|l|}{ Absorptive Capacity } \\
\hline Science and Eng graduates & 0.011 & 0.24 & & 0.001 & 0.81 & \\
\hline Other graduates & 0.051 & 1.25 & & -0.001 & -0.89 & \\
\hline Training for innovation & -2.017 & -1.58 & & -0.052 & -1.50 & \\
\hline Investment for innovation & 1.164 & 0.92 & & 0.042 & 1.10 & \\
\hline \multicolumn{7}{|l|}{ Sectoral Indicators } \\
\hline Retail & -5.187 & -2.42 & ** & -0.03 & -0.43 & \\
\hline Hotels and hospitality & -10.496 & -4.78 & $* * *$ & -0.028 & -0.38 & \\
\hline Transport and Communications & 2.835 & 1.14 & & -0.076 & -1.15 & \\
\hline \multicolumn{7}{|l|}{ Financial services } \\
\hline Real estate, renting & 14.192 & 3.15 & $* * *$ & 0.158 & 1.83 & * \\
\hline Computer services, R\&D & 9.889 & 2.03 & ** & -0.005 & -0.05 & \\
\hline Other Business Services & 4.603 & 1.59 & & -0.025 & -0.37 & \\
\hline Constant & 21.741 & 9.93 & $* * *$ & 0.035 & 0.50 & \\
\hline Estimation & OLS & & & OLS & & \\
\hline$F(.,)$. & 29.99 & & & 2.61 & & \\
\hline $\mathrm{R}^{2}$ & 0.54 & & & 0.094 & & \\
\hline Observations & 651 & & & 542 & & \\
\hline
\end{tabular}

Notes: Observations are weighted to give regionally representative results. * denotes significance at 10 per cent level; ** significant at 5 per cent level and ${ }^{* * *}$ significant at 1 per cent level.

Sources: UK Innovation Survey 2005, Annual Business Inquiry, 2004 and 2005. 
Figure 1: Innovation, R\&D, Exporting and Productivity in NI Services

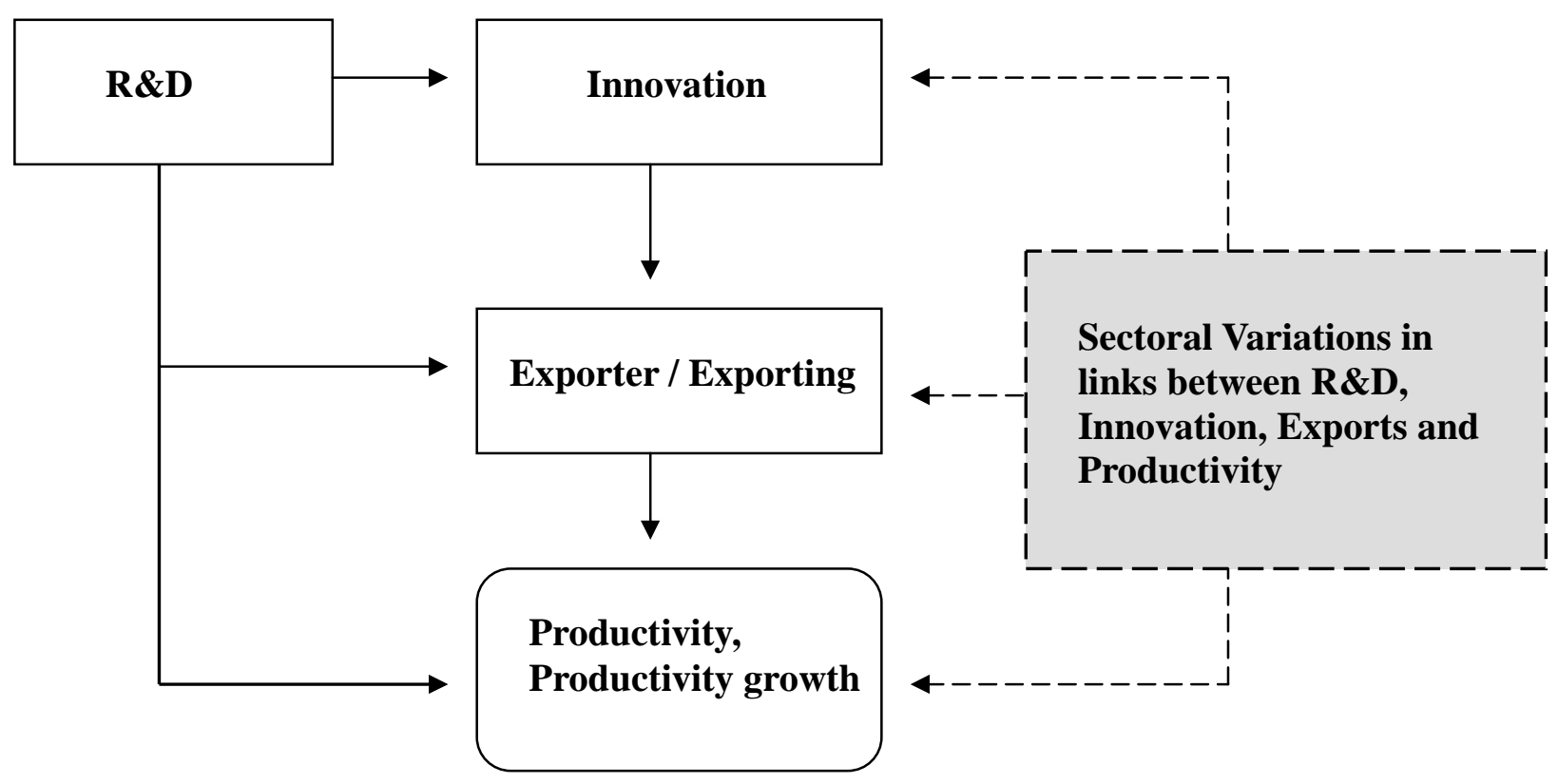




\section{Annex 1: Correlations between Variables}

Service Innovation

Marketing Innovation

Strategic Innovation

AMT Innovation

Organisational Innovation

Innovation Success

Exporter

Exports as share of sales (2005, \%)

GVA per employee (2005

GVA growth per employee (2005)

Local group members

External group members

Local suppliers

External suppliers

Local customers

External customers

Local competitors

External competitors

Lxcaties, consultants

External labs, consultants

Local universities

External universities

Research and Development

Employment (2002, nos)

Firm established post 2000

Part of larger group

\begin{tabular}{|c|c|c|c|c|}
\hline $\begin{array}{l}\text { Service } \\
\text { Innovation }\end{array}$ & $\begin{array}{l}\text { Marketing } \\
\text { Innovation }\end{array}$ & $\begin{array}{l}\text { Strategic } \\
\text { Innovation }\end{array}$ & $\begin{array}{l}\text { AMT } \\
\text { Innovation }\end{array}$ & $\begin{array}{l}\text { Organis. } \\
\text { Innovation }\end{array}$ \\
\hline 1.00 & & & & \\
\hline 0.31 & 1.00 & & & \\
\hline 0.27 & 0.52 & 1.00 & & \\
\hline 0.27 & 0.49 & 0.46 & 1.00 & \\
\hline 0.20 & 0.47 & 0.57 & 0.50 & 1.0 \\
\hline 0.64 & 0.33 & 0.30 & 0.26 & 0.2 \\
\hline 0.13 & 0.07 & 0.11 & 0.11 & 0.12 \\
\hline 0.17 & 0.08 & 0.07 & 0.11 & 0.1 \\
\hline 0.13 & 0.04 & 0.03 & 0.07 & 0.0 \\
\hline 0.08 & 0.07 & 0.05 & 0.10 & 0.0 \\
\hline 0.25 & 0.20 & 0.12 & 0.17 & 0.0 \\
\hline 0.06 & 0.10 & 0.06 & 0.11 & 0.1 \\
\hline 0.13 & 0.14 & 0.07 & 0.09 & 0.0 \\
\hline 0.26 & 0.24 & 0.18 & 0.33 & 0.2 \\
\hline 0.25 & 0.17 & 0.05 & 0.15 & 0.1 \\
\hline 0.32 & 0.28 & 0.21 & 0.28 & 0.2 \\
\hline 0.19 & 0.18 & 0.10 & 0.13 & 0.1 \\
\hline 0.25 & 0.24 & 0.18 & 0.26 & 0.1 \\
\hline 0.17 & 0.19 & 0.12 & 0.21 & 0.1 \\
\hline 0.17 & 0.14 & 0.06 & 0.15 & 0.1 \\
\hline 0.21 & 0.17 & 0.08 & 0.22 & 0.1 \\
\hline 0.15 & 0.15 & 0.12 & 0.16 & 0. \\
\hline 0.42 & 0.40 & 0.26 & 0.32 & 0.2 \\
\hline 0.01 & 0.03 & 0.03 & 0.14 & 0.1 \\
\hline 0.00 & 0.01 & 0.11 & -0.02 & 0. \\
\hline 0.12 & 0.14 & 0.21 & 0.13 & \\
\hline
\end{tabular}

\section{Innovation \\ Success}

Exporter

Exports \%
of sales
GVA per

GVA

growth

Local 
Riskiness of innovation

Costs of innovation

Costs of finance

Availability of finance

Lack of qualified personnel

Lack of info on markets

Market dominated by established

firms

Uncertain demand for innovation

Need to meet UK regulations

Need to meet EU regulations

Science and Eng graduates

Other graduates

Training for innovation

Investment for innovation

Local or regional

UK national

EU assistance

External group members

Local suppliers

External suppliers

Local customers

External customers

Local competitors

External competitors

Local laboratories, consultants

External labs, consultants

Local universities

External universities

Research and Development

$\begin{array}{rrrrrrrrrrr}0.11 & 0.14 & 0.10 & 0.16 & 0.09 & 0.04 & 0.02 & -0.04 & 0.02 & -0.01 & 0.09 \\ 0.08 & 0.12 & 0.10 & 0.14 & 0.09 & 0.08 & -0.01 & -0.03 & 0.00 & 0.02 & 0.06 \\ 0.10 & 0.11 & 0.10 & 0.20 & 0.13 & 0.05 & -0.03 & -0.03 & -0.04 & -0.02 & 0.12 \\ 0.06 & 0.05 & 0.05 & 0.11 & 0.08 & 0.10 & -0.06 & 0.00 & -0.05 & -0.01 & 0.00 \\ 0.04 & 0.07 & 0.11 & 0.11 & 0.13 & 0.05 & 0.01 & -0.04 & -0.01 & 0.02 & 0.04 \\ 0.03 & 0.10 & 0.12 & 0.14 & 0.17 & 0.07 & 0.03 & 0.03 & 0.03 & 0.07 & -0.03 \\ & & & & & & & & & & \\ -0.09 & 0.01 & 0.04 & 0.02 & 0.02 & -0.07 & 0.03 & -0.02 & -0.02 & 0.01 & 0.06 \\ -0.01 & 0.11 & 0.07 & 0.17 & 0.11 & 0.01 & 0.06 & -0.02 & 0.01 & 0.04 & 0.14 \\ 0.10 & 0.11 & 0.08 & 0.13 & 0.07 & 0.02 & 0.11 & 0.07 & 0.03 & 0.01 & 0.06 \\ 0.11 & 0.10 & 0.07 & 0.12 & 0.05 & 0.02 & 0.13 & 0.08 & 0.04 & 0.01 & 0.01 \\ 0.15 & 0.21 & 0.17 & 0.15 & 0.19 & 0.19 & 0.27 & 0.30 & 0.11 & 0.11 & 0.07 \\ 0.12 & 0.10 & 0.07 & 0.16 & 0.13 & 0.10 & 0.13 & 0.12 & 0.11 & 0.02 & 0.14 \\ 0.33 & 0.32 & 0.26 & 0.33 & 0.27 & 0.29 & 0.07 & 0.11 & 0.15 & 0.08 & 0.19 \\ 0.30 & 0.32 & 0.21 & 0.28 & 0.21 & 0.24 & 0.12 & 0.12 & 0.06 & 0.09 & 0.21 \\ 0.18 & 0.20 & 0.14 & 0.17 & 0.14 & 0.26 & 0.10 & 0.08 & 0.11 & 0.10 & 0.16 \\ 0.18 & 0.20 & 0.15 & 0.21 & 0.19 & 0.22 & 0.18 & 0.21 & 0.06 & 0.07 & 0.16 \\ 0.14 & 0.13 & 0.18 & 0.14 & 0.10 & 0.12 & -0.02 & 0.00 & 0.16 & 0.11 & 0.13\end{array}$

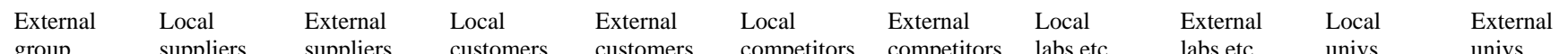

suppliers

customers

$\begin{array}{ll}1.00 & \\ 0.07 & 1.00 \\ 0.35 & 0.17 \\ 0.15 & 0.65 \\ 0.18 & 0.37 \\ 0.19 & 0.58 \\ 0.10 & 0.33 \\ 0.24 & 0.49 \\ 0.24 & 0.37 \\ 0.34 & 0.24 \\ 0.16 & 0.13 \\ 0.04 & 0.17\end{array}$

1.00
0.35
0.60
0.25
0.54
0.37
0.54
0.50
0.37
0.21

1.00
0.38
0.58
0.45
0.45
0.50
0.41
0.27
0.22

1.00
0.54
0.65
0.35
0.47
0.38
0.32
0.22

1.00
0.44
0.43
0.30
0.46
0.16
0.13

1.00
0.26
0.62
0.37
0.37
0.23

1.00
0.29
0.42
0.20

1.00

0.49

0.52 


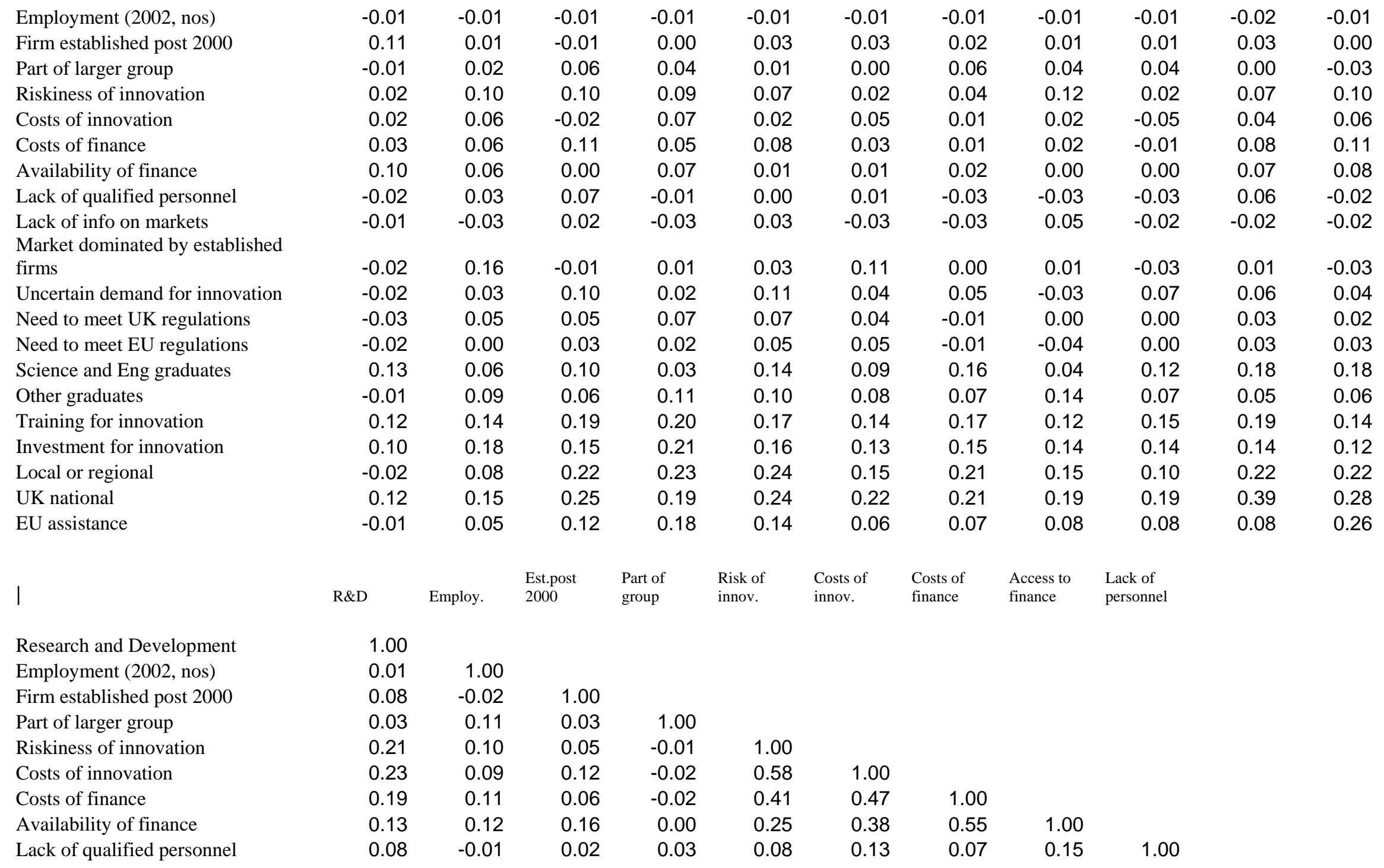


Lack of info on markets

Market dominated by established

firms

Uncertain demand for innovation

Need to meet UK regulations

Need to meet EU regulations

Science and Eng graduates

Other graduates

Training for innovation

Investment for innovation

Local or regional

UK national

EU assistance

Lack of info on markets

Market dominated by established

firms

Uncertain demand for innovation

Need to meet UK regulations

Need to meet EU regulations

Science and Eng graduates

Other graduates

Training for innovation

Investment for innovation

Local or regional

UK national

EU assistance

\begin{tabular}{|c|c|c|c|c|c|c|c|c|c|c|c|}
\hline 0.06 & 0.00 & 0.07 & 0.09 & 0.21 & 0.19 & 0.16 & 0.23 & 0.29 & & & \\
\hline 0.06 & 0.12 & 0.07 & 0.03 & 0.24 & 0.20 & 0.13 & 0.14 & 0.10 & & & \\
\hline 0.17 & 0.15 & -0.03 & 0.04 & 0.22 & 0.18 & 0.16 & 0.10 & 0.18 & & & \\
\hline 0.16 & 0.09 & 0.00 & -0.03 & 0.24 & 0.20 & 0.31 & 0.18 & 0.11 & & & \\
\hline 0.12 & 0.10 & -0.03 & -0.01 & 0.19 & 0.17 & 0.27 & 0.16 & 0.08 & & & \\
\hline 0.30 & -0.03 & 0.06 & 0.07 & 0.11 & 0.15 & 0.02 & 0.03 & 0.01 & & & \\
\hline 0.16 & -0.04 & 0.00 & 0.03 & 0.05 & 0.11 & 0.06 & 0.04 & -0.02 & & & \\
\hline 0.44 & 0.01 & 0.07 & 0.06 & 0.17 & 0.20 & 0.19 & 0.12 & 0.02 & & & \\
\hline 0.41 & -0.01 & 0.02 & 0.06 & 0.09 & 0.14 & 0.08 & 0.09 & 0.05 & & & \\
\hline 0.21 & -0.02 & -0.01 & -0.04 & 0.11 & 0.13 & 0.16 & 0.04 & 0.01 & & & \\
\hline 0.32 & -0.02 & 0.03 & 0.05 & 0.01 & 0.11 & 0.12 & 0.02 & 0.01 & & & \\
\hline 0.11 & -0.01 & 0.00 & 0.00 & 0.05 & 0.09 & 0.14 & 0.02 & -0.02 & & & \\
\hline $\begin{array}{l}\text { Lack of } \\
\text { info. }\end{array}$ & $\begin{array}{l}\text { Market } \\
\text { dominated }\end{array}$ & $\begin{array}{l}\text { Uncertain } \\
\text { demand }\end{array}$ & $\begin{array}{l}\text { UK } \\
\text { regulations }\end{array}$ & $\begin{array}{l}\text { EU } \\
\text { regulations }\end{array}$ & $\begin{array}{l}\text { Science } \\
\text { graduates }\end{array}$ & $\begin{array}{l}\text { Other } \\
\text { graduates }\end{array}$ & $\begin{array}{l}\text { Training } \\
\text { for innov. }\end{array}$ & $\begin{array}{l}\text { Inv. } \\
\text { for innov. }\end{array}$ & $\begin{array}{l}\text { Local govt } \\
\text { support }\end{array}$ & $\begin{array}{l}\text { UK govt } \\
\text { support }\end{array}$ & $\begin{array}{l}\text { EU } \\
\text { support }\end{array}$ \\
\hline \multicolumn{12}{|l|}{1.00} \\
\hline 0.17 & 1.00 & & & & & & & & & & \\
\hline 0.18 & 0.33 & 1.00 & & & & & & & & & \\
\hline 0.19 & 0.22 & 0.17 & 1.00 & & & & & & & & \\
\hline 0.17 & 0.20 & 0.14 & 0.88 & 1.00 & & & & & & & \\
\hline 0.07 & 0.06 & 0.05 & 0.07 & 0.07 & 1.00 & & & & & & \\
\hline 0.02 & 0.03 & 0.04 & 0.01 & 0.02 & 0.15 & 1.00 & & & & & \\
\hline 0.06 & 0.00 & 0.07 & 0.14 & 0.13 & 0.27 & 0.13 & 1.00 & & & & \\
\hline 0.08 & 0.01 & 0.04 & 0.14 & 0.13 & 0.21 & 0.18 & 0.55 & 1.00 & & & \\
\hline 0.00 & -0.03 & 0.00 & 0.03 & 0.02 & 0.19 & 0.12 & 0.19 & 0.12 & 1.00 & & \\
\hline 0.00 & 0.05 & 0.03 & -0.01 & 0.00 & 0.33 & 0.13 & 0.19 & 0.11 & 0.47 & 1.00 & \\
\hline-0.02 & -0.03 & -0.03 & 0.02 & 0.02 & 0.05 & 0.05 & 0.06 & 0.05 & 0.26 & 0.32 & \\
\hline
\end{tabular}




\section{References}

Audretsch, D B. 1998. Agglomeration and the location of innovative activity. Oxford Review of Economic Policy 14 (2):18-29.

Bessant, J., and H. Rush. 1995. Building Bridges For Innovation - The Role Of Consultants In Technology-Transfer. Research Policy 24 (1):97-114.

Bilbao-Osorio, B, and A Rodriguez-Pose. 2004. From R\&D to innovation and economic growth in the EU. Growth and Change 35:434-455.

Bleaney, M, and K Wakelin. 2002. Efficiency, innovation and exports. Oxford Bulletin of Economics and Statistics 64:3-15.

Blind, K, and A Jumgmittag. 2004. Foreign direct investment, imports and innovations in the service industry. Review of Industrial Organisation 25:205227.

Boschma, R A. 2005. Proximity and Innovation: A Critical Assessment. Regional Studies 39 (1):61-74.

Cainelli, G, R Evangelista, and M Savona. 2006. Innovation and Economic performance in services: a firm-level analysis. Cambridge Journal of Economics 30:435-458.

Cohen, W M, and D A Levinthal. 1989. Innovation and Learning: the two faces of R\&D. The Economic Journal 99:569-596.

— 1990. Absorptive capacity: a new perspective on learning and innovation. Administrative Science Quarterly 35:128-152.

Cooke, P, and K Morgan. 1998. The associational economy: Firms, regions and innovation. Oxford; Oxford University Press.

Crépon, B, E Duguet and J Mairesse. 1998. Research, Innovation and Productivity: An econometric analysis at the firm level. Economics of Innovation and New Technology 7:115-158.

Czarnitzki, D, and A Spielkamp. 2003. Business services in Germany: Bridges for innovation. The Service Industries Journal 23 (2):1-30.

de Jong, J P, J Bruins, A Dolfsma, and J Meijaard. 2003. Innovation in service firms explored: what how and why? In Strategic Study B200205. the Netherlands.: EIM Business and Policy Research. 
Den Hertog, P. 2000. Knowledge-intensive business services as co-producers of innovation. International Journal of Innovation Management 4 (4):491-528.

DETI (2006) 'UK Innovation Survey 2005: Northern Ireland Results, May 2006, Department of Enterprise Trade and Investment, Belfast. Available at: http://www.detini.gov.uk/cgi-bin/downdoc?id=2197.

Djellal, F, and F Gallouj. 1998. Innovation in Services: the results of a postal survey. SI4S project, TSER programme (European Commission, University of LilleIFRESI).

Evangelista, R. 2000. Sectoral Patterns of Technological Change in Services. Economics of Innovation and New Technology:183-221.

Faulconbridge, J. R. 2006. Stretching tacit knowledge beyond a local fix? Global spaces of learning in advertising professional service firms. Journal of Economic Geography 6 (4):517-540.

Fielding, D. 2003. Investment, Employment and Political Conflict in Northern Ireland. Oxford Economic Papers 55:512-535.

Foss, N. 2004. Resources, Firms and Strategies. Oxford: Oxford University Press.

Freel, M S. 2005. Patterns of Innovation and skills in small firms. Technovation 25:123-134.

Gallaher, M P, A N Link, and J E Petrusa. 2006. Innovation in the US Service Sector, Routledge Studies in Innovation, Organisation and Technology. Abingdon: Routledge.

Gallouj F (2002) 'Interactional innovation: a neo-Schumpeterian model' in J Sundbo and L Fuglsang (eds) Innovation and Strategic Reflexivity, New York; Routledge, 29-56.

Gallouj, F. and Weinstein, O. 1997. Innovation in services, Research Policy, vol. 26, 537-56

Geroski, P A. 1990. Innovation, Technological Opportunities and Market Structure. Oxford Econonomic Papers 42:586-602.

Gertler, M. 2001. Best Practice? Geography, learning and the institutional limits to strong convergence. Journal Of Economic Geography 1:75-99.

Gertler, M. 2004. Manufacturing Culture. Oxford: Oxford University Press.

Gourlay, A, J Seaton, and J Suppakitjarak. 2005. The determinants of export behaviour in UK service firms. Service Industries Journal 25:879-889. 
Grabher, G (1993) 'The weakness of strong ties: the lock-in of regional development in the Ruhr Area' G. Grabher, ed. The Embedded Firm. On the Socioeconomics of Interfirm Relations, London: Routledge

Greene, W H. 2005. Econometric Analysis. 5th ed. Upper Saddle River, New Jersey: Prentice-Hall.

Griffith, R, S Redding, and J Van Reenan. 2003. R\&D and Absorptive Capacity: Theory and Empirical Evidence. Scandinavian Journal of Economics 105 (1):99-118.

Griliches, Z. 1992. The Search for Research-And-Development Spillovers. Scandinavian Journal of Economics 94:S29-S47.

H M Treasury. 2000. Productivity in the UK: the Evidence and the Government's Approach.

Harris, R I D, and M Trainor. 1995. Innovation and R\&D in Northern Ireland Manufacturing: A Schumpeterian Approach. Regional Studies 29:593-604.

Hemphill, T A. 2003. Cooperative strategy, Technology Innovation and Product Development in Industrial Companies. International Journal of Production Economics 69 (2):169-176.

Hewitt-Dundas, N, B Anderson-Callaghan, M Crone, J Murray, and S Roper. 2002. Learning from the Best - Knowledge Transfers from Mulitinational Plants in Ireland - A North-South Comparison. Belfast: NIERC/EAC.

Hewitt-Dundas, N. 2006. Resource and capability constraints to innovation small and large plants. Small Business Economics 26:257-277.

Horn, Paul M. 2005. The Changing Nature of Innovation. Research Technology Management 48 (6):28-33.

Howells, J. 2000a. Services and systems of innovation. In Knowledge and Innovation in the new service economy, edited by B. Andersen. Northampton, MA: Edward Elgar Publishing Ltd.

Howells, J. 2000b. International coordination of technology flows and knowledge activity in innovation. International Journal Of Technology Management 19 (7-8):806-819.

Hulshoff, H E, F M J Westhof, J J Kirchhoff, B A Kirchhoff, and S T Walsh. 1998. New services: strategic exploratory survey of a dynamic phenomenon. Zoetermeer: EIM. 
Iansiti, M, and R Levien. 2004. The Keystone Advantage. Boston: Harvard Business School Press.

Jordan, D, and E O’Leary. 2007. Sources of innovation in Irish SMEs: Evidence from two Irish regions. Paper read at British-Irish Regional Science Association Annual Conference, at Bangor.

Joshi, A W, and S Sharma. 2004. Customer Knowledge Development: Antecedents and Impact on New Product Performance. Journal of Marketing 68 (4):47-59.

Keller, W. 2004. International technology diffusion. Journal of Economic Literature 42 (3):752-782.

Lachenmaier, and Wößmann . 2006. Does innovation causes exports? Evidence from exogenous innovation impulses and obstacles using German micro data. Oxford Economic Papers 58:317-350.

Leiponen, A. 2005. Organization of Knowledge and Innovation: The Case of Finnish Business Services. Industry and Innovation, 12 (2):185-203.

Link, A N, D Paton, and D S Siegel. 2005. An Econometric Analysis of Trends in Research Joint Venture Activity. Managerial and Decision Economics 26 (2):149-158.

Lööf, H, and A Heshmati. 2001. On the Relationship between Innovation and Performance: A Sensitivity Analysis. Stockholm School of Economics.

—. 2002. Knowledge captial and performance heterogeneity: A firm level innovation study. International Journal of Production Economics 76:61-85.

Love, J H, and M A Mansury. 2007. External Linkages, R\&D and Innovation Performance in US Business Services. Industry and Innovation 14: 477-496.

Love, J H, and S Roper. 1999. The determinants of innovation: R\&D, technology transfer and networking effects. Review of Industrial Organisation 15 (1):4364.

Maddala, G. 1973. Limited Dependent and Qualitative Variables in Econometrics. New York: Cambridge University Press.

Mansury M A and Love J H (2008) 'Innovation, productivity and growth in US business services: a firm-level analysis, Technovation, 28: 52-62.

Muller, E, and A Zenker. 2001. Business services as actors of knowledge transformation: The role of KIBS in regional and national innovation systems. Research Policy 30 (9):1501-1516. 
Nelson, R R, and S Winter. 1982. An Evolutionary Theory of Economic Change. Cambridge, Massachusetts: Harvard University Press.

OECD. 2007. Summary report of the study of globalisation and innovation in the business services sector, edited by G. a. S. Adjustment. Paris.

Robson, P. J. A., and M. Freel. 2008. Small firm exporters in a developing economy context: evidence from Ghana. Entrepreneurship And Regional Development 20 (5):431-450.

Robson, S, and L Ortmans. 2006. First findings from the UK Innovation Survey 2005. Economic Trends 628.

Roper, S. 2004. 'Regional Innovation Policy: An effective way of reducing spatial disparities in small nations?' in D. Felsenstein and Portonov, B, (eds) Economic Policy in Small Economics: Springer-Verlag.

Roper, S, J Du, and J H Love. 2008. Modelling the innovation value chain. Research Policy, 37, 961-977.

Roper, S, and N Hewitt-Dundas. 2001. Grant assistance and small firm development in Northern Ireland and the Republic of Ireland. Scottish Journal of Political Economy 48 (1):99-117.

Roper, S, and J H Love. 2002. Innovation and Export Performance: Evidence from UK and German Manufacturing Plants. Research Policy 31:1087-1102.

Shelanski, H A, and P G Klein. 1995. Empirical research in transaction cost economics: a review and assessment. Journal of Law, Economics and Organization 11 (2):335-361.

Silvestrou, R, L Fitzgerlad, R Johnston, and C Grant. 1992. Towards a classification of service processes. International Journal of Service Industry Management 3:62-75.

Smith, D J, and D Tranfield. 2005. Talented suppliers? Strategic change and innovation in the UK aerospace industry. $R \& D$ Management 35 (1):37-49.

Sterlacchini, A. 1999. Do innovative activities matter to small firms in non-R\&Dintensive industries? An application to export performance. Research Policy 28:819-832.

Tether, B S. 2005. Do Services Innovate (Differently)? Insights from the European Innobarometer Survey. Industry and Innovation 12:153-184.

Veugelers, R, and B Cassiman. 1999. Make and Buy in Innovation Strategies: Evidence from Belgian manufacturing firms. Research Policy 28 (1):63-80. 
von Hippel, E. 1998. Economics of product development by users: The impact of "sticky" local information. Management Science 44 (5):629-644.

Wagner J (2007) 'Exports and productivity: a survey of the evidence from firm-level data', The World Economy, 30, 60-82.

Wakelin, K. 1998. Innovation and Export Behaviour at the Firm Level. Research Policy 26:829-841.

Wolff, J A and Pett, T L (2006) 'Small firm performance: Modeling the role of product and process improvements', Journal of Small Business Management, 44, 2, 268-284.

Wood, P. 2005. A service-informed approach to regional innovation - or adaptation? The Service Industries Journal 25 (4):429-445.

Zahra, S A, and G George. 2002. Absorptive capacity: a review, re-conceptualization, and extension. Academy of Management Review 27:185-203. 